IZA DP No. 10091

Short-Run Externalities of Civic Unrest:

Evidence from Ferguson, Missouri

Seth Gershenson

Michael S. Hayes

July 2016 


\title{
Short-Run Externalities of Civic Unrest: Evidence from Ferguson, Missouri
}

\author{
Seth Gershenson \\ American University \\ and IZA
}

Michael S. Hayes

Rutgers University, Camden

Discussion Paper No. 10091
July 2016

IZA

P.O. Box 7240

53072 Bonn

Germany

Phone: +49-228-3894-0

Fax: +49-228-3894-180

E-mail: iza@iza.org

Any opinions expressed here are those of the author(s) and not those of IZA. Research published in this series may include views on policy, but the institute itself takes no institutional policy positions. The IZA research network is committed to the IZA Guiding Principles of Research Integrity.

The Institute for the Study of Labor (IZA) in Bonn is a local and virtual international research center and a place of communication between science, politics and business. IZA is an independent nonprofit organization supported by Deutsche Post Foundation. The center is associated with the University of Bonn and offers a stimulating research environment through its international network, workshops and conferences, data service, project support, research visits and doctoral program. IZA engages in (i) original and internationally competitive research in all fields of labor economics, (ii) development of policy concepts, and (iii) dissemination of research results and concepts to the interested public.

IZA Discussion Papers often represent preliminary work and are circulated to encourage discussion. Citation of such a paper should account for its provisional character. A revised version may be available directly from the author. 
IZA Discussion Paper No. 10091

July 2016

\section{ABSTRACT}

\section{Short-Run Externalities of Civic Unrest: Evidence from Ferguson, Missouri ${ }^{*}$}

We document externalities of the civic unrest experienced in Ferguson, MO following the police shooting of an unarmed black teenager. Difference-in-differences and synthetic control method estimates compare Ferguson-area schools to neighboring schools in the greater St. Louis area and find that the unrest led to statistically significant, arguably causal declines in students' math and reading achievement. Attendance is one mechanism through which this effect operated, as chronic absence increased by five percent in Ferguson-area schools. Impacts were concentrated in elementary schools and at the bottom of the achievement distribution and spilled over into majority black schools throughout the area.

JEL Classification: $\quad$ 12, R00

Keywords: civic unrest, Ferguson, achievement gaps, natural experiment, externalities

Corresponding author:

Seth Gershenson

School of Public Affairs

American University

4400 Massachusetts Avenue, NW

Washington, DC 20016-8070

USA

E-mail: gershens@american.edu

\footnotetext{
* The authors thank David Deming, Dave Marcotte, Nicholas Papageorge, and seminar participants at the College Board and the 2016 SOLE Meetings for providing helpful comments. Elizabeth Pancotti provided helpful research assistance. Any remaining errors are our own.
} 


\section{Introduction}

The August 2014 police shooting of Michael Brown, an unarmed black teenager, in Ferguson, MO prompted local protests against real and perceived racial inequities in police departments' treatment of citizens and communities in the Ferguson area northwest of St. Louis. These protests quickly attracted protestors and media coverage from across the country. Similar protests, and accompanying civic unrest, spread to several major American cities during the latter half of 2014, both in response to the events in Ferguson and to similar incidents in which unarmed black males were killed by police. Notable examples include the killings of 43 year old Eric Garner in New York and 12 year old Tamir Rice in Cleveland. Unrest in Ferguson and in other parts of the country continued into 2015, when the officers involved in previous incidents were neither indicted nor formally charged. New events generated additional unrest, such as the death of Freddie Gray while in police custody in Baltimore in April 2015.

Ensuing protests, demonstrations, civic unrest, riots, and growth of socio-political movements (e.g., Black Lives Matter) renewed public discussion of the stark racial differences in citizens' exposure to, and interactions with, law enforcement and the criminal justice system. ${ }^{1}$ Of course, whether these events and movements create long-run, permanent changes in policing practices, racial segregation, and living conditions in inner city, traditionally disadvantaged communities remains to be seen.

In the short run, however, episodes of civic unrest associated with protests potentially impose both direct and indirect costs on society. This is not to say that demonstrations and protests associated with social movements are "bad" in the sense that they necessarily reduce social welfare. Indeed, they may be catalysts for change and create social benefits that far outweigh any costs. Rather, understanding the size, distribution, and burdens of these costs is crucial for policy makers and community leaders seeking to minimize short-run harm. For example, direct costs of the riots in Ferguson include upwards of $\$ 4$ million in property damage (Unglesbee, 2014) and as much as \$20 million in spending by local and state governments, mainly for overtime for first responders (Davis, 2014). Wenger (2015 a, b) reports similar direct financial costs of the 2015 Baltimore riots.

\footnotetext{
${ }^{1}$ See, for example, Mullainathan's (2015) piece in the New York Times. More recently, three police shootings of black men in Baton Rouge, LA, Dallas, TX, and St. Paul, MN in July 2016 have touched off another round of discussion and protests regarding black communities' relationships with law enforcement agencies and the criminal justice system.
} 
There are other potential short run costs that policy makers and institutions can potentially mitigate. However, such costs have received relatively little attention thus far, perhaps because they are inherently difficult to quantify. Doing so is important, as identifying the nature and magnitude of negative externalities is paramount to devising effective and efficient policy responses. The current study investigates one potential class of such indirect costs: the causal effect of prolonged, acute civic unrest on schools and student achievement.

Identifying the impact of civic unrest on student outcomes is important for at least three reasons. First, there is likely room for schools and communities to implement interventions and policies that mitigate the harm associated with civic unrest. Second, educational success is likely to play a key role in breaking cycles of poverty and violence in disadvantaged neighborhoods, given the well documented association between educational attainment and earnings (Blundell, Dearden, and Sianesi, 2005; Card, 1999), civic engagement (Dee, 2004; Milligan, Moretti, and Oreopoulos, 2004), and crime (Deming, 2011; Lochner and Moretti, 2004; Machin, Marie, and Vujic, 2011). Finally, in an era of consequential accountability in which schools are sanctioned for low aggregate performance on standardized tests (e.g., Figlio \& Loeb, 2011), sanctions that result from civic unrest and similar factors outside schools' control present an additional hurdle that schools serving disadvantaged communities must overcome.

The police shooting of Michael Brown in Ferguson, MO provides an ideal natural experiment with which to analyze the impact of intense, prolonged civic unrest and attention to racial disparities in interactions with the criminal justice system on student achievement: the shooting occurred on the eve of the 2014-15 school year and intermittent protests occurred throughout the subsequent 9 months (i.e., the entirety of the 2014-15 school year). While Ferguson schools were already relatively low performing and serving disproportionately large numbers of high-needs students compared to other schools in the St. Louis area, it is possible that the added stress and distraction of the protests, riots, violence, out of town visitors, and media attention further harmed student achievement, through some combination of causing student and teacher absences, shifting classroom time from curricular instruction to discussion of current events, changing home and parental behaviors, causing mental stress and concern for the safety of students' neighborhoods and family members, and by disrupting learning environments.

To account for preexisting differences between schools in the Ferguson area and schools in other parts of the state, we attempt to identify the impact of civic unrest using difference-in- 
differences (DD) methods that explicitly control for preexisting differences (and differential trends) between schools. We do so using school-level data on annual academic achievement and student attendance, both overall and for the subset of high-needs students, and by school type, for 2010-2015. ${ }^{2}$ District-level synthetic control method (SCM) analyses (Abadie \& Gardeazabal, 2003) yield similar results.

This paper contributes to a growing body of literature that investigates the effects of exposure to stressors such as acute violence, natural disasters, and community-wide violence (i.e., civil wars) on student achievement. Particularly relevant to the context of urban centers in the U.S., a series of papers by Patrick Sharkey and coauthors (Sharkey, 2010; Sharkey et al., 2012; Sharkey et al., 2014) estimate the effect of students' geographical proximity to homicides on various cognitive measures and standardized tests in inner city neighborhoods in Chicago and New York by exploiting arguably random temporal variation in homicides within neighborhoods. Beland and Kim (2016) estimate the impact of school shootings (i.e., homicides that occurred on school grounds) using a similar identification strategy. While these studies consistently find evidence of a short-run effect of exposure to one-off incidents of acute violence on student achievement, their implications for the harm attributable to unexpected, longer lasting neighborhood- or city-level disruptions is unclear. One of the few studies to investigate the impact of sustained exposure to a communitywide traumatic event in the U.S. context is Gershenson and Tekin (2015). The authors find that exposure to the "Beltway Sniper" attacks, which occurred during a three week period in October 2002, reduced primary school students' math achievement. They use a difference-in-differences strategy that compares schools in the I95 corridor that were within five miles of a sniper attack to those that were not, which is similar to the DD strategy applied in the current study.

While Gershenson and Tekin (2015) provide evidence that less acute, longer term exposure to external stressors can harm student achievement, the stress and disruption attributable to the civic unrest in Ferguson was fundamentally different in at least two ways. First, it was sustained, with intermittent outbreaks of extreme disruption, over an entire academic year. Second, the source of the stress was not a random targeting, but rather a specific incident that caused long simmering racial and socioeconomic tensions in the community to erupt. Thus, the current study contributes to this literature by documenting the short-run impact of sustained

\footnotetext{
${ }^{2}$ We henceforth refer to academic years by spring semester.
} 
civic unrest in a relatively segregated, disadvantaged community on students' educational outcomes. Additionally, we investigate the mechanisms through which such effects operate.

The paper proceeds as follows: Section 2 reviews the timeline of events in Ferguson, MO that precipitated and sustained the civic unrest throughout the 2015 academic year and describes the geography and district catchment areas used to define the treatment. Section 3 describes the data. Section 4 describes the identification strategy. The main school-level DD results are presented in Section 5. Section 6 presents the SCM results and Section 7 concludes.

\section{Background}

\subsection{Ferguson Timeline}

The civic unrest in Ferguson, MO began shortly after Michael Brown, an 18 year old black male, was shot and killed by a white police officer on August 9, 2014. ${ }^{3}$ Brown was unarmed and some witnesses claimed that he was surrendering at the time he was shot. Shortly thereafter, crowds gathered at the scene, and later that evening some rioting and looting occurred on nearby West Florissant Avenue. For the next ten days or so, the Ferguson area witnessed several rounds tense standoffs and encounters between protestors and police. There was a heavy media presence as well. The strong police response, which included militaristic vehicles and arms, may have escalated the tension. Tensions eased as Brown's funeral was held on August 25, though a series of sporadic protests, arrests, and announcements from the authorities occurred throughout September and October.

A second round of intense violence, riots, and standoffs between protestors and police occurred in the second half of November 2014, this time due to a grand jury's failure to indict the police officer involved in the shooting of Michael Brown. This series of protests and rioting lasted for about one week. Protests spread to other cities across the country in response to the grand jury's decision. Smaller outbreaks of violence in Ferguson occurred in March and April of 2015, in response to the Ferguson police chief's resignation and the death of Freddie Gray in police custody in Baltimore, respectively.

The cycle of civic unrest came full circle when additional looting and shootings occurred in concert with demonstrations and protests commemorating the one year anniversary of

\footnotetext{
${ }^{3}$ Detailed timelines are available from numerous media outlets, including The Telegraph and The New York Times (part 1, part 2).
} 
Brown's death in August 2015. Thus, from the time of the shooting two weeks before school was scheduled to start, throughout the entire 2014-15 academic year and into the subsequent summer vacation, residents of Ferguson experienced a persistent, elevated state of civic unrest, disruption, stress, and violence. Viewed through the lens of a natural experiment, the civic unrest experienced in Ferguson throughout the 2014-15 academic year provides ideal leverage with which to identify the impact of civic unrest on short-run student outcomes.

\subsection{Ferguson Geography}

The St. Louis Metropolitan Statistical Area (MSA) straddles the Mississippi River and includes counties in both Missouri and Illinois. ${ }^{4}$ According to the 2010 U.S. Census, the MSA was home to about 2.8 million individuals and was about $77 \%$ white, $18 \%$ black, 2.5 percent Hispanic, and 2.1\% Asian. St. Louis County, in which Ferguson is located, is the most populous county in the MSA. We restrict our analysis to the St. Louis MSA because its labor market and demographics are quite different from those in other parts of Missouri. We further restrict our analytic sample (and donor pool in SCM analyses) to schools and districts on the Missouri side of the MSA, because the Missouri and Illinois tests are not directly comparable.

Defining the "treated group" is not straightforward for several reasons. First, media reports and discussion of the unrest frequently refer to the city of Ferguson, which is technically accurate as this is the jurisdiction in which the shooting of Michael Brown and much of the looting and protests occurred. However, Ferguson-Florissant School District is not synonymous with Ferguson City. In fact, Ferguson City proper contains several smaller school districts, notably Riverview Gardens District, whose catchment area includes the specific sites of Brown's shooting and the initial protests on West Florissant Ave. Moreover, Brown himself actually completed high school in the Normandy District, which is adjacent to the South of both the Ferguson and Riverview Gardens districts. A fourth independent school district, Jennings, is surrounded by these three districts, and by St. Louis City District to the East. Thus, as the map in Figure 1 makes clear, it is potentially misleading to consider Ferguson as the sole "treated" district. In the baseline school-level DD models, we therefore consider schools in the

\footnotetext{
${ }^{4}$ The six St. Louis MSA counties in Missouri are Lincoln, Warren, St. Charles, Franklin, Jefferson, and St. Louis County (which contains Ferguson). St. Louis is an independent city in Missouri in the MSA. Appendix Figure A.1 shows a map of the entire MSA.
} 
geographically contiguous block of four districts (Ferguson, Jennings, Normandy, and Riverview Gardens) as treated. We also estimate models that allow the treatment effect to vary across these four districts and investigate the sensitivity of the main results to using a broader definition of treatment that adds three additional geographically contiguous districts to the treatment group: St. Louis City, University City, and Hazelwood. In district-level SCM analyses, we consider Ferguson to be the treated district but exclude Jennings, Normandy, and Riverview Gardens from the donor pool. The main results are robust to these, and to alternative configurations, of the treatment group, as well as to including all MO schools in the control group. We also use a triple-difference specification to test whether majority black schools in the MSA but outside the immediate vicinity of Ferguson were affected by the racial tensions brought to light by discussions and protests associated with the shooting of Michael Brown.

\section{Data}

We analyze school-level data from 2010-2015 made available by Missouri’s Department of Elementary and Secondary Education via their Comprehensive Data System. ${ }^{5}$ Achievement data comes from school-level aggregate performance on Missouri Assessment Program (MAP) standardized tests that are administered in grades 3-8 and in certain high school subjects in the spring of each academic year. The state codes student performance on these exams into four mutually exclusive performance categories: advanced, proficient, basic, and below basic. The percent of all schools' and districts' students that fit in each category are publicly released. Our analysis focuses on the top and bottom categories, as we find that changes in advanced are offset by changes in proficient and changes in below basic are offset by changes in proficient.

In addition to these aggregate school-wide performance measures, in accordance with the No Child Left Behind Act (NCLB), the state also reports similar aggregate measures separately by specific test and separately by student subgroups. Specifically, the state reports results for what it calls "Super Subgroup" students, who are high-needs students who are in at least one of the following specific subgroups: black, Hispanic, students with disabilities, English language learners, or low income students. ${ }^{6}$ Because many students in the Ferguson area qualify for SuperSubgroup status, we report results both overall and for the Super Subgroup, as the latter ensures

\footnotetext{
${ }^{5}$ See http://mcds.dese.mo.gov/Pages/default.aspx.

${ }^{6}$ Low-income is measured by students' eligibility for free/reduced price school lunches (FRL).
} 
that the DD analyses compare the performance of high-needs students in treated and control schools.

Missouri's Comprehensive Data System also provides a wealth of information about schools in the state, which we summarize along with the academic performance data in Table 1. We report means separately by treatment status for schools in the St. Louis MSA, which highlights baseline differences between Ferguson area schools and other schools in the MSA. ${ }^{7}$ There are 53 schools in the four treated districts and 439 schools elsewhere in the MSA. Several stark differences emerge. First, in both reading and math, Ferguson area schools perform significantly lower control schools: on average, students in Ferguson area schools are about twice as likely to score "Below Basic" and less than half as likely to score "Advanced" as students in other districts in the MSA.

Second, there is also an attendance differential between treated and control schools, for both male and female students, that is less pronounced among low-income (FRL) students. ${ }^{8}$ The attendance rates reported in Missouri refer to the percentage of a school's students who were absent fewer than 10 percent of school days. Being absent more than 10 percent of school days is a commonly used definition of chronic absence (Balfanz \& Byrnes, 2012), so the reported attendance rates are best interpreted as the percentage of students who are not chronically absent. These are informative measures of school attendance, which is an important input in the education production function: chronically absent students score about 0.12 test-score standard deviations lower than students who are rarely absent (Gershenson et al., 2016). Attendance is an intermediate educational outcome that may have been affected by the civic unrest in Ferguson, and therefore a possible channel through which civic unrest affects academic achievement. We investigate this hypothesis below.

Finally, table 1 summarizes numerous school characteristics. Teachers and administrators actually have higher salaries in treated schools, on average, than their counterparts in control schools. Ferguson area teachers are also slightly more experienced than their counterparts elsewhere in the MSA. However, student-teacher ratios are larger in treated districts. Finally, the socio-demographic composition of the enrollments in Ferguson area schools is quite different

\footnotetext{
${ }^{7}$ As described in section two, the baseline "treatment" group includes schools in four districts: Ferguson, Jennings, Normandy, and Riverview Gardens.

${ }^{8}$ Unfortunately, attendance is not reported at the Super-Subgroup level.
} 
from the rest of the MSA: these schools are 90 percent black and 82 percent FRL, on average, while control schools are only 27 percent black and 45 percent FRL. This concentration of low income, racial minority students has been a focus of many discussions of the events that precipitated the civic unrest in Ferguson (e.g., Goodman, 2014 a; Kneebone, 2014). These differences underscore the importance of properly accounting for pre-existing differences between treated and control schools in the econometric analysis and the value of the SuperSubgroup performance measures, which facilitate comparisons of high-needs students in and outside Ferguson.

Figures 2 and 3 motivate the empirical analysis by providing suggestive evidence of a departure from trend in Ferguson area schools in 2015 that is unlikely to be due to chance. Figure 2 plots the average school's deviance from the statewide school average in percent below basic in math in each year, separately for control and treated schools. We report these figures relative to the state-wide, year-specific mean to account for statewide changes to the tests, and make the results comparable over time. Two aspects of Figure 2 are worth noting. First, trends in overall and Super-Subgroup math achievement in both treated and control schools are similar in the pretreatment (2010-2014) period. This suggests that any effects of the unrest in Ferguson are not driven by pre-existing differential trends between treated and control groups, though we formally test this assumption below. Second, the trend line for control schools continues to be flat in 2015, the treatment year, while there is a notable uptick in the frequency of below-basic scores in treated schools in 2015, both overall and among Super-Subgroup students. Indeed, Figure 2 shows that what was approximately a ten percentage point gap between treated and control schools in percent below basic in math roughly doubled to a 20 percentage point gap in 2015 , both overall and among high-needs students. Appendix Figure A.2 shows a similar pattern in the doubling of the treatment-control gap in the percent of students scoring below basic in reading.

Figure 3 addresses the stylized fact that test scores are noisy and prone to mean reversion by plotting the full distribution of within-school, year-to-year changes in percent below basic in math for the 2012-2013, 2013-2014, and 2014-2015 transitions. Treated Ferguson-area schools are shaded black and control schools are shaded gray. Panel A shows a preponderance of black in the distribution's right tail, indicating that most Ferguson-area schools exhibited relatively large increases in percent below basic. Specifically, more than half of the top 5 percent declines and 60 percent of the top 1 percent declines occurred in the Ferguson area, despite Ferguson 
schools representing only about 11 percent of all schools. This is in stark contrast to panels B and $\mathrm{C}$ of Figure 3, which present analogous figures for the two transitions prior to the unrest in Ferguson. Here, Ferguson-area schools constitute only 20 percent of the top 1 percent declines and only 26 to 33 percent of top 5 percent declines. As in Figure 2, Figure 3 suggests that while Ferguson-area schools were underperforming other schools in the St. Louis MSA, they experienced a pronounced departure from trend in 2015, the year of the civic unrest in Ferguson.

\section{Identification Strategy}

As suggested by Figures 2 and 3, Ferguson-area (treated) schools are systematically different from other schools in the MSA and there may have been secular statewide changes in student performance over the period 2010-2015. We address these confounding factors by using school-level data to estimate a variety of difference-in-differences (DD) style regressions that control for school fixed effects (FE), year FE, time-varying observed school characteristics, and school-specific time trends. The preferred baseline model conditions on time-varying school characteristics, school FE, year FE, and school-specific linear time trends. Specifically, we estimate models of the form

$$
Y_{s t}=\tau \text { Ferguson }_{s} \times 1\{t=2015\}+\beta X_{s t}+\theta_{s}+\delta_{t}+\gamma t \theta_{s}+\varepsilon_{s t},
$$

where $s$ and $t$ index schools and academic years, respectively; $Y$ is a measure of school performance on statewide exams; Ferguson is a binary indicator equal to one if the school was in one of the four districts in the immediate vicinity of the protests, and zero otherwise; $1\{\cdot\}$ is the indicator function; $X$ is a vector of the time-varying school characteristics summarized in table 1; $\theta$ and $\delta$ are school and year FE, respectively; and $\varepsilon$ is an idiosyncratic error. Equation (1) will also be augmented to condition on quadratic school time trends. The parameter of interest is $\tau$, which represents the departure from trend of Ferguson-area schools in the 2015 academic year. Standard errors are clustered at the district level, which makes inference robust to arbitrary serial correlation within schools and districts, as schools are nested in districts.

The key identifying assumption for OLS estimation of equation (1) is a variant of the parallel slopes assumption: i.e., conditional on school-specific linear time trends, schools in and outside the Ferguson area were trending similarly prior to the 2015 school year. We provide two pieces of empirical evidence that suggest this assumption holds. First, we estimate versions of equation (1) that either restrict $\beta=0$, restrict $\gamma=0$, replace the linear school time trends with 
linear district time trends, or augment the model to include quadratic school time trends. Importantly, if estimates of $\tau$ are similar across these alternative specifications, the baseline

results are unlikely to be the result of differential pre-existing trends between "treated" and "control" schools. Second, we estimate event study versions of equation (1) that interact

Ferguson with each year indicator, which provides a direct test for "effects" of the civic unrest in years prior to the unrest experienced in 2015. If the event study analysis yields significant "effects" in Ferguson in the years prior to 2015, we would be concerned that the DD estimates of equation (1) are biased by pre-existing differential trends in the treated schools. As shown in section 5, the results of these sensitivity analyses corroborate a causal interpretation of OLS estimates of $\tau$ in equation (1). Section 6 presents district-level synthetic control estimates that further corroborate the finding that civic unrest in Ferguson, MO harmed student achievement.

\section{Results}

\subsection{Baseline Difference-in-Differences Estimates}

Table 2 reports estimates of the baseline DD regression model (equation 1). Column 1 reports estimates of parsimonious specifications that condition only on school and year FE. Moving from left to right, each column of Table 2 augments the model estimated in column 1 to include a richer conditioning set: column 2 adds time-varying school controls, column 3 adds linear district-specific time trends, column 4 adds linear school-specific time trends (which subsume the district trends), and column 5 adds quadratic school-specific time trends. Each row of Table 2 reports the DD estimate for one of eight different school-level performance measures: math and reading, percent below basic and percent advanced, for all students and for Super Subgroup students. Each cell of Table 2 reports the DD estimate of $\tau$ from a unique regression.

Several aspects of Table 2 merit discussion. First, the estimates are remarkably stable across columns, within rows. In other words, the baseline DD estimates are robust to controlling (or not) for time-variant school characteristics and various school and district time trends. This stability strongly suggests that the DD estimates are not biased by pre-existing differential trends (i.e., failure of the parallel trends assumption) (Angrist \& Pischke, 2009). We address this issue further in the context of event study specifications below. Moreover, Appendix Tables A.1 and A.2 show that the main results presented in Table 2 are robust to weighting by school 
enrollments (Solon, Haider, \& Wooldridge, 2015) and to using a broader definition of "treatment" that includes three additional nearby school districts, respectively. ${ }^{9}$

Second, for the "Percent Below Basic" measures, there are practically large, statistically significant effects across all subjects and student subgroups. The baseline linear school trends specification in column 4 yields overall estimates of 16.9 and 10.4 percentage point increases in the percent of students who rate as "below basic" in math and reading, respectively. These effects are substantively large, as they represent a doubling of the percent of students below basic in math and a 55 percent increase in the percent of students below basic in reading. The effects on the fraction of Super-Subgroup students scoring below basic are smaller, yet still statistically and economically significant: increases of 10.9 percentage points $(68 \%)$ in math and 6.9 percentage points $(36 \%)$ in reading. There are also negative effects on "Percent Advanced" in both subjects, though these point estimates are not statistically significant for Super-Subgroup students in models that condition on school time trends. While these point estimates are smaller in magnitude and less precisely estimated than those for "Below Basic," in the treated Fergusonarea districts, only a small base of students ever score "Advanced." These results are troubling, as they suggest that many marginal students fell further behind while some high achievers may have been harmed as well. ${ }^{10}$ Finally, since there is relatively little heterogeneity in effects by subject, the sensitivity analyses that follow focus on math results.

The robustness of the baseline results to controlling for school and district-specific time trends, and for time-varying school observables, suggests that the DD estimates are not driven by pre-existing differential trends in the treated (Ferguson area) schools. In Table 3, we formally test this assumption using an event study version of equation (1) that fully interacts the Ferguson indicator with the full set of year FE. Relative to the omitted 2010 reference group, the other 2011-2014 pre-treatment interactions tend to be statistically insignificant and small in magnitude. In fact, they are often the opposite sign of the actual 2015 treatment effect, which itself remains similar in magnitude to the baseline estimates reported in Table 2 and strongly statistically significant for three of the four outcomes. Coupled with the results in Table 2, the event study

\footnotetext{
${ }^{9}$ The three additional treated districts are St. Louis City, University City, and Hazelwood. The first two are southeast of Ferguson. Hazelwood wraps around the Northern end of Ferguson. ${ }^{10}$ Civic unrest did not affect school enrollments. Rather, it appears that the increase in percent "Below Basic" was offset by a decline in percent "Basic" and the decline in percent "Advanced" was offset by an increase in percent "Proficient."
} 
estimates reported in Table 3 provide further evidence that the main identifying assumption holds and, as a result, that the baseline DD estimates can be given a causal interpretation.

\subsection{Heterogeneous Effects}

The baseline model discussed thus far assumes a constant effect across grade levels and across treated schools. There is no reason this must be so, of course, as previous research on the impact of exposure to community violence finds larger effects among younger students (Gershenson \& Tekin 2015; Sharkey et al., 2014) and variation across schools and districts in distance and association to the events that unfolded in Ferguson in 2015 suggests that some districts were treated more intensely than others. Tables 4 and 5 generalize the baseline model to allow for heterogeneous effects by district and grade level, respectively.

Table 4 reports estimates of an augmented version of the baseline linear school trends model (equation 1) in which the treatment indicator is disaggregated into four separate district indicators. In all models, the four interaction terms (district-specific treatments) are jointly statistically significant. While the main result of a positive, sizable, and statistically significant effect on the percent Below Basic is upheld in all four "treated" districts, the effect is about twice as large in Ferguson and Normandy as it is in Jennings and Riverview Gardens. This is perhaps unsurprising, as Ferguson was the name mentioned in most media accounts of the events and home to much of the violence that occurred along W. Florissant Ave and Normandy is the district that Michael Brown graduated from. Thus, for different reasons, it is intuitive that the impact on achievement was more severe in these districts.

Table 5 reports estimates of the baseline linear school trends model (equation 1) separately for math performance in elementary, middle, and high schools. The overall estimates in column 1 are repeated from Table 2 to provide a baseline. Table 5 shows that the main results presented in Table 2 were primarily driven by the response in elementary schools, which is consistent with the results of Sharkey et al. (2014). ${ }^{11}$ The estimated effects in high schools are generally in the same direction, but smaller in magnitude and never statistically significant. Sharkey et al. (2014) hypothesize that this could be because older students, who have grown up in disadvantaged neighborhoods, are more resilient to unexpected shocks and disruption.

\footnotetext{
${ }^{11}$ Appendix Table A.3 shows that this result is robust to instead looking at performance on endof-year math tests in third, fifth, and eighth grades and high school Algebra 1 exams.
} 
Alternatively, this result could be due to cognitive ability being more malleable at younger ages (e.g., Cunha, Heckman, Lochner, \& Masterov, 2006).

\subsection{Possible Mechanisms}

Having documented that the civic unrest experienced in the Ferguson area in 2015 likely harmed student achievement, we now investigate some potential channels through which such effects might have operated. The absence of student- or teacher-level data limits the channels that we can investigate, but school data on the percentage of students who were not chronically absent is reported. The causal link between attendance and achievement is well established (e.g., Aucejo \& Romano, 2014; Gershenson et al., 2016; Goodman, 2014 b), and it is plausible that the civic unrest in Ferguson affected student attendance by creating safety concerns over the commute to school, causing students to disengage from school more generally, or distracting parents from ensuring that students attended school on a regular basis. Column 1 of Table 6 reports baseline DD estimates of the impact of the unrest in Ferguson on Ferguson-area schools' overall attendance rates and attendance rates for specific socio-demographic groups. Specifically, this variable measures the percent of students who are absent less than 10 percent of school days. Columns 2-4 do the same separately for elementary, middle, and high schools since Table 5 showed that achievement effects were concentrated in elementary schools. Thus each cell in Table 6 reports the DD estimate for a unique regression.

Overall, the first row of column 1 shows that the civic unrest in Ferguson was associated with a 3.1 percentage point decrease in the attendance measure, which means that chronic absence rates increased by this amount. This effect is strongly statistically significant and represents an approximate decline of four percent in treated schools. The effect was similar for both male and female students, and IEP students. The elementary school estimates in column 2 are quite similar to those in column 1, while the estimates for middle and high schools in columns 3 and 4, respectively, tend to be smaller and are imprecisely estimated. Overall, the absence results presented in Table 6 are consistent with the causal interpretation of the civic unrest in Ferguson harming student achievement in elementary schools. Moreover, these results suggest that increased absenteeism was an important channel through which civic unrest harmed achievement in Ferguson-area elementary schools. 
Another way to disentangle the mechanisms through which the events in Ferguson, MO affected schools is to consider that the racially charged events and conversations in Ferguson might well have affected predominantly black schools and communities across the MSA, even those not in close proximity to the unrest. For example, stress, fear, and concern caused by the highly publicized shooting of an unarmed black teenager could easily disrupt schools in other parts of the MSA, especially given the amount of national media attention that the unrest in Ferguson received. Other possible channels, such as decreases in attendance due to safety concerns, are likely more specific to the immediate Ferguson area. Accordingly, we estimate a triple-difference version of equation (1) that allows the unrest in Ferguson to affect all majorityblack schools in the MSA, and for this effect to differ in Ferguson area schools, which themselves are uniformly majority black. Estimates of these triple-difference models are reported for math achievement and attendance, overall and in elementary schools, in Table 7.

Before estimating the full triple-difference model, column 1 of Table 7 simply changes the treatment indicator in the baseline model from "Ferguson area" to "majority black." The resulting point estimates in column 1 are smaller than those reported in Tables 2 and 6, but of the same sign and statistical significance. Intuitively, this suggests that the impact of the unrest in Ferguson was not isolated to the four "treated" districts, though the effects were larger in magnitude in districts physically closer to the unrest. Column 2 formalizes this idea by estimating the triple-interaction model that allows the response of majority black schools to vary by proximity to the civic unrest in Ferguson. As expected, the triple interaction terms show that the effects were larger in magnitude in Ferguson area schools, though not significantly so.

Columns 3 and 4 repeat this exercise for elementary schools, which experienced the largest declines in student achievement and attendance. In elementary schools, column 4 shows that the impact of the unrest in Ferguson was significantly larger in the majority-black schools in the Ferguson-area than in other majority-black schools in the St. Louis MSA. Specifically, the overall and super-subgroup effects of the civic unrest in Ferguson on percent below basic in math were $66 \%$ and $125 \%$ larger, respectively, in the Ferguson area than in majority black schools elsewhere in the MSA. Similarly, the effects of the civic unrest in Ferguson on attendance rates was $86 \%$ larger in the Ferguson area than in majority black schools elsewhere in the MSA. These results are consistent with the unrest in Ferguson having a causal impact on student achievement in Ferguson-area schools, particularly in elementary schools. Moreover, 
these results suggest that attendance was an important, but not the only, mechanism through which civic unrest affected student learning.

One interpretation of the triple-difference estimates reported in Table 7 is that the psychic costs of stress and changes in the allocation of instructional time away from academic topics covered by MAP tests and towards conversations about race, social and criminal justice, and inequality were more important channels through which achievement was affected than direct disruptions to schools, households, and neighborhoods in the Ferguson area. That the impact spread to other parts of the MSA, state, and nation is plausible, as the nightly news coverage of the events in Ferguson, New York, Baltimore, Cleveland, and elsewhere made racial inequities in the U.S. salient and a topic of conversation in majority-black schools. ${ }^{12}$ Together with the effect on student attendance, these findings reinforce the main finding of the baseline schoollevel DD analyses: civic unrest experienced in Ferguson, MO had a nontrivial, arguably causal impact on elementary school students' math and reading achievement, which occurred at least partly due an increase in chronic absenteeism, and was concentrated at the bottom of the achievement distribution.

\section{Synthetic Control Method}

While the difference-in-differences (DD) analyses and robustness checks presented in section 5 provide arguably convincing evidence of a causal effect of the civic unrest experienced in the Ferguson area during the 2015 academic year on student achievement, two potential concerns about the DD identification strategy remain. First, the DD research design is only as good as the control units utilized in the analysis, and there is intuitive appeal in using a datadriven, objective procedure for selecting comparison units (Abadie, Diamond, \& Hainmueller, 2015). Second, there is a potential issue regarding statistical inference, since we cluster the standard errors by district and only four districts are treated in the baseline model (Conley \& Taber, 2011). In this section, we address both issues by using the Synthetic Control Method (SCM) (Abadie, Diamond, \& Hainmueller, 2010; Abadie \& Gardeazabal, 2003) to (i) identify a

\footnotetext{
${ }^{12}$ Another possible interpretation of the triple interaction terms in column 4 of Table 7 is that they represent lower bounds of the impact of the civic unrest in Ferguson on math achievement. This would be the case if, for example, some other event or policy shock disproportionately affected majority black schools in the St. Louis MSA in 2015.
} 
"synthetic" Ferguson school district, (ii) identify the impact of the civic unrest in Ferguson on student achievement in the district, and (iii) conduct inference using placebo tests. ${ }^{13}$

\subsection{Synthetic Ferguson}

We focus the SCM analysis on Ferguson as the sole treated district, as this is the district in which much of the unrest occurred, and the DD analysis finds that this is the district most affected by the unrest. We exclude the other six Ferguson-area districts that comprise the "broad treatment" from the donor pool (i.e., the pool of possible comparison districts) but include all other districts in the St. Louis MSA. The matching algorithm articulated in Abadie et al. (2015) identifies a "synthetic Ferguson" that is a weighted average of two districts: Ritenour and Maplewood-Richmond Heights. Both are nearby Ferguson and appear in the map in Figure 1.

Figure 4.A plots the percent below basic in math in the real and synthetic Ferguson districts, relative to the statewide mean, from 2010 to 2015. From 2010 to 2014, Ferguson and its synthetic control follow the same pattern and are nearly overlapping. This is consistent with the raw data plotted in Figure 2 and indicates that the SCM matching algorithm identified a valid synthetic control. Then, in 2015, there is an increase in the percentage of students scoring below basic in math in both the actual and synthetic Ferguson districts. However, the increase in the real Ferguson is noticeably steeper than that in the synthetic control. This difference indicates an impact of more than ten percentage points, which is reassuring, since it is similar in size to the impacts identified in the school-level DD analyses. The smaller uptick in the synthetic Ferguson is consistent with spillover effects of the acute unrest in the Ferguson area on neighboring districts. Figure 4.B presents this ten percentage point effect in a visually appealing way, by plotting the annual difference between Ferguson and its synthetic control in each year. Prior to treatment, this differences fluctuates around zero. The departure from this trend in 2015 can be interpreted as the impact of the unrest on math achievement in the district.

\subsection{Placebo Tests}

Inference on the SCM estimate of the treatment effect is conducted via empirical placebo tests (Abadie et al. 2015). Specifically, we conduct placebo SCM analyses that assign treatment in the wrong years (i.e., 2012 and 2013) and to the wrong districts (i.e., districts outside the

\footnotetext{
${ }^{13}$ See Abadie, Diamond, \& Hainmueller (2015) for an intuitive introduction to these methods.
} 
Ferguson area). If the SCM estimates reported in Figure 4 reflect a causal relationship between civic unrest and math achievement, these placebo analyses should not yield similar estimates of an "impact" on control districts or in non-treatment years.

First, we estimate the SCM matching procedure assuming that the treatment occurred in 2012 and ignoring 2015 data. We repeat this exercise assuming treatment in 2013. Both exercises identify Ritenour District as the same synthetic Ferguson, so Figure 5 plots Ferguson relative to Ritenour (the synthetic Ferguson) from 2010-2014. Importantly, the two lines follow similar trends (i.e., they are parallel) and there is no notable departure from trend in Ferguson's percent below basic following either placebo treatment year (2012 or 2013). Importantly, this indicates that the effect identified in Figure 4 reflects a causal impact of the civic unrest and is not an artifact of a "bad" synthetic control.

Second, we estimate a synthetic control for each of the 43 school districts in the St. Louis MSA outside the "broad" Ferguson area. As in the actual SCM, we allow for a placebo effect of the unrest in Ferguson during the 2015 school year. Figure 6.A plots the difference in percent below basic in math between each placebo district and its synthetic control between 2010 and 2015. The difference for Ferguson is in bold and the effect in Ferguson is among the largest "effects" observed in Figure 6.A, though five other districts experienced similarly large increases. However, some of those five placebo districts experienced significant fluctuations in the pre-treatment period as well, which implies a poorly fit synthetic control. Following Abadie et al. (2015), we remove this noise from the figure by discarding the 26 districts that had root mean square prediction errors greater than three times that of Ferguson's. The resulting figure is presented in Figure 6.B. Here, it is clear that Ferguson's departure from its synthetic control is an outlier relative to the majority of districts in the St. Louis MSA. Intuitively, Figure 6 provides evidence that the SCM estimate of an impact of the civic unrest on student achievement in Ferguson is not due to random chance. For example, Figure 6.B suggests a $2 / 17(\approx 0.12)$ chance of randomly observing an effect as large as that observed in Ferguson (i.e., an empirical p value).

\section{Conclusion}

This paper documents the negative impact on student achievement of the many months of civic unrest that followed the police shooting of an unarmed black teenager in Ferguson, MO. We find statistically significant, arguably causal declines in students' math and reading 
achievement in Ferguson-area elementary schools relative to other schools in the St. Louis MSA. Smaller negative effects are found in majority-black schools elsewhere in the MSA. These difference-in-difference (DD) and triple-difference estimates are not driven by pre-existing differential trends in treated schools and are robust to controlling for time-varying school characteristics and linear and quadratic school-specific time trends. Effects are relatively large, particularly at the lower end of the math-score distribution. For example, a conservative estimate suggests that the fraction of high-needs students scoring "below basic" in math increased by about 10 percentage points following the unrest. At the district level, synthetic control method (SCM) estimates corroborate the baseline DD results.

Reductions in achievement were concentrated in elementary schools, and appear to have been at least partly driven by corresponding increases in student absences: the rate of chronic absence increased by about four percentage points (5\%) in Ferguson-area elementary schools. However, attendance is unlikely the sole mechanism through which the civic unrest in Ferguson, $\mathrm{MO}$ affected student achievement in the area, as smaller, but statistically significant, declines in achievement occurred in other majority-black school districts farther away from the physical unrest. For example, the events in Ferguson might have affected schools through other channels, such as creating stress and causing teachers and parents to reallocate instructional time away from math and reading skills and towards non-tested topics such as race, inequality, and the criminal justice system. Of course, without objective data on these intermediate outcomes, it is impossible to definitively say to what extent the unrest in Ferguson affected student achievement through these channels, in Ferguson or elsewhere in the MSA, state, and country.

Since attendance and lost instructional time are likely mechanisms through which civic unrest may have affected achievement, we contextualize our results by comparing them to those from similar analyses of the impact of disruptions to school schedules on school-level proficiency rates. For example, Marcotte and Hemelt (2008) find that ten unscheduled, weatherrelated school closings reduced third and fifth grade math proficiency rates by between 5 and 7 percentage points in Maryland. Similarly, Gershenson and Tekin (2015) find that proximity to the 2002 Beltway Sniper Attacks reduced schools' fifth-grade math proficiency rates by about 5 percentage points in schools serving black and low-income communities. These effects are similar in size to the conservative triple-difference estimates reported in Table 7 and smaller than the baseline estimates in Table 2 of the current study. That the effects of the unrest in Ferguson 
are larger than those of the beltway sniper attacks is intuitive, since even if the two events created similar levels of stress and safety concerns, the unrest in Ferguson played out over an entire school year while those in the sniper case lasted about three weeks, early in the school year. Still, these impacts are large enough to change schools' standings under consequential accountability regimes such as No Child Left Behind (Gershenson \& Tekin, 2015; Marcotte and Hemelt, 2008). The attendance results in the current study further our understanding of the mechanisms through which external disruptions to school environments and school schedules can affect student achievement and highlight the importance of attendance in the education production function (Goodman, 2014 b).

More generally, our results highlight the potential benefits of local and state interventions that respond to civic unrest and related distractions and disruptions to schools. For example, providing additional resources, support, and guidance to affected schools and communities might reduce the harm to achievement associated with such events. Weems et al. (2009) describe one school-based intervention that reduced test anxiety in a predominantly black sample of students who were exposed to Hurricane Katrina. This type of reactive policy and support would be further justified by the fact that the civic unrest in Ferguson occurred in what were already relatively disadvantaged and under-resourced schools and communities. 


\section{REFERENCES}

Abadie, A., \& Gardeazabal, J. (2003). The economic costs of conflict: A case study of the Basque Country. American Economic Review, 93(1), 113-132.

Abadie, A., Diamond, A., \& Hainmueller, J. (2010). Synthetic control methods for comparative case studies: Estimating the effect of California's tobacco control program. Journal of the American Statistical Association, 105(490), 493-505.

Abadie, A., Diamond, A., \& Hainmueller, J. (2015). Comparative politics and the synthetic control method. American Journal of Political Science, 59(2), 495-510.

Angrist, J. D., \& Pischke, J. S. (2009). Mostly harmless econometrics: An empiricist's companion. Princeton University Press.

Aucejo, E. M., \& Romano, T. F. (2014). Assessing the effect of school days and absences on test score performance. CEP Discussion Paper No 1302.

Balfanz, Robert, \& Byrnes, Vaughan. (2012). Chronic absenteeism: Summarizing what we know from nationally available data. Baltimore, MD: Johns Hopkins University Center for Social Organization of Schools.

Beland, L-P., \& Kim, D. 2016. The effect of high school shootings on schools and student performance. Educational Evaluation and Policy Analysis, 38(1), 113-126

Birdsall, C. (2016). The synthetic control method for comparative case studies: An application estimating the effect of managerial discretion under performance management. Forthcoming, International Public Management Journal. DOI: 10.1080/10967494.2015.1121178

Blundell, Richard, Lorraine Dearden, and Barbara Sianesi. 2005. Evaluating the effect of education on earnings: Models, methods and results from the National Child Development Survey. Journal of the Royal Statistical Society: Series A (Statistics in Society), 168 (3):473-512.

Card, David. 1999. The Causal Effect of Education on Earnings. Handbook of Labor Economics 3:1801-1863.

Conley, T. G., \& Taber, C. R. (2011). Inference with "difference in differences" with a small number of policy changes. The Review of Economics and Statistics, 93(1), 113-125.

Cunha, F., Heckman, J. J., Lochner, L., \& Masterov, D. V. (2006). Interpreting the evidence on life cycle skill formation. Handbook of the Economics of Education, 1, pp. 697-812.

Davis, Elliot. (2014). The cost taxpayers will have to shell out for Ferguson. Fox 2 News, St. Louis. http://fox2now.com/2014/12/09/the-cost-taxpayer-will-have-to-shell-out-for-ferguson/ (accessed October 22, 2015). 
Dee, Thomas S. 2004. Are there civic returns to education? Journal of Public Economics, 88(9): 1697-1720.

Deming, D. J. (2011). Better Schools, Less Crime? The Quarterly Journal of Economics, 126(4), 2063-2115.

Figlio, D., \& Loeb, S. (2011). School accountability. In E. Hanushek, S. Machin, \& L.

Woessmann (Eds.), Handbook of the Economics of Education, vol. 3, (pp. 383-421). Amsterdam: North Holland.

Gershenson, S., Jacknowitz, A., \& Brannegan, A. (2016). Are student absences worth the worry in U.S. primary schools? Education Finance \& Policy. DOI:10.1162/EDFP_a_00207

Gershenson, S., \& Tekin, E. (2015). The effect of community traumatic events on student achievement: Evidence from the beltway sniper attacks. NBER Working Paper No. 21055.

Goodman, H. A. (2014 a). Ferguson resulted from Republican talking points that ignore the economic segregation of blacks in America. Huff Post Politics. Accessed October 27, 2015 http://www.huffingtonpost.com/h-a-goodman/ferguson-resulted-from-re_b_5680955.html.

Goodman, J. (2014 b). Flaking out: Student absences and snow days as disruptions of instructional time. NBER Working Paper No. 20221.

Grossman, Michael. 2006. Education and Nonmarket Outcomes. Handbook of the Economics of Education 1:577-633.

Kneebone, E. (2014). Ferguson, Mo. Emblematic of Growing Suburban Poverty. Brookings - f The Avenue. http://www.brookings.edu/blogs/the-avenue/posts/2014/08/15-ferguson-suburbanpoverty Accessed October 27, 2015.

Lochner, Lance and Enrico Moretti. 2004. The Effect of education on crime: Evidence from prison inmates, arrests, and self-reports. American Economic Review 94 (1):155-189.

Machin, Stephen, Olivier Marie, and Suncica Vujic. 2011. The crime reducing effect of education. The Economic Journal 121 (552):463-484.

Marcotte, D. E., \& Hemelt, S. W. (2008). Unscheduled school closings and student performance. Education Finance and Policy, 3(3), 316-338.

Milligan, Kevin, Enrico Moretti, and Philip Oreopoulos. 2004. Does Education Improve Citizenship? Evidence from the United States and the United Kingdom. Journal of Public Economics 88(9):1667-1695.

Mullainathan, S. 2015. Police Killings of Blacks: Here Is What the Data Say. New York Times: The Upshot. October 16, 2015. 
Sharkey, P. (2010). The acute effect of local homicides on children's cognitive performance. Proceedings of the National Academy of Sciences, 107(26), 11733-11738.

Sharkey, P. T., Tirado-Strayer, N., Papachristos, A. V., \& Raver, C. C. (2012). The effect of local violence on children's attention and impulse control. American Journal of Public Health, 102(12), 2287-2293.

Sharkey, P., Schwartz, A. E., Ellen, I. G., \& Lacoe, J. (2014). High stakes in the classroom, high stakes on the street: The effects of community violence on students' standardized test performance. Sociological Science, 1, 199-220.

Solon, G., Haider, S. J., \& Wooldridge, J. M. (2015). What are we weighting for? Journal of Human Resources, 50(2), 301-316.

Unglesbee, B. 2014. Buildings destroyed in Ferguson riots worth millions. St. Louis Business Journal. December 4, 2014. http://www.bizjournals.com/stlouis/news/2014/12/04/buildingsdestroyed-in-ferguson-riots-worth.html (accessed October 28, 2015).

Wenger, Y. 2015. Unrest will cost city \$20 million, officials estimate. Baltimore Sun, May 26, 2015. http://www.baltimoresun.com/news/maryland/baltimore-city/bs-md-ci-unrest-cost20150526-story.html (accessed October 28, 2015).

Wenger, Y. 2015. One estimate of business damage from Baltimore riot estimated at \$9M, total cost unknown. Baltimore Sun, May 13, 2015. http://www.baltimoresun.com/news/maryland/baltimore-city/bs-md-ci-damage-estimate20150513-story.html (accessed October 28, 2015). 
Figure 1. Map of Ferguson Area Districts

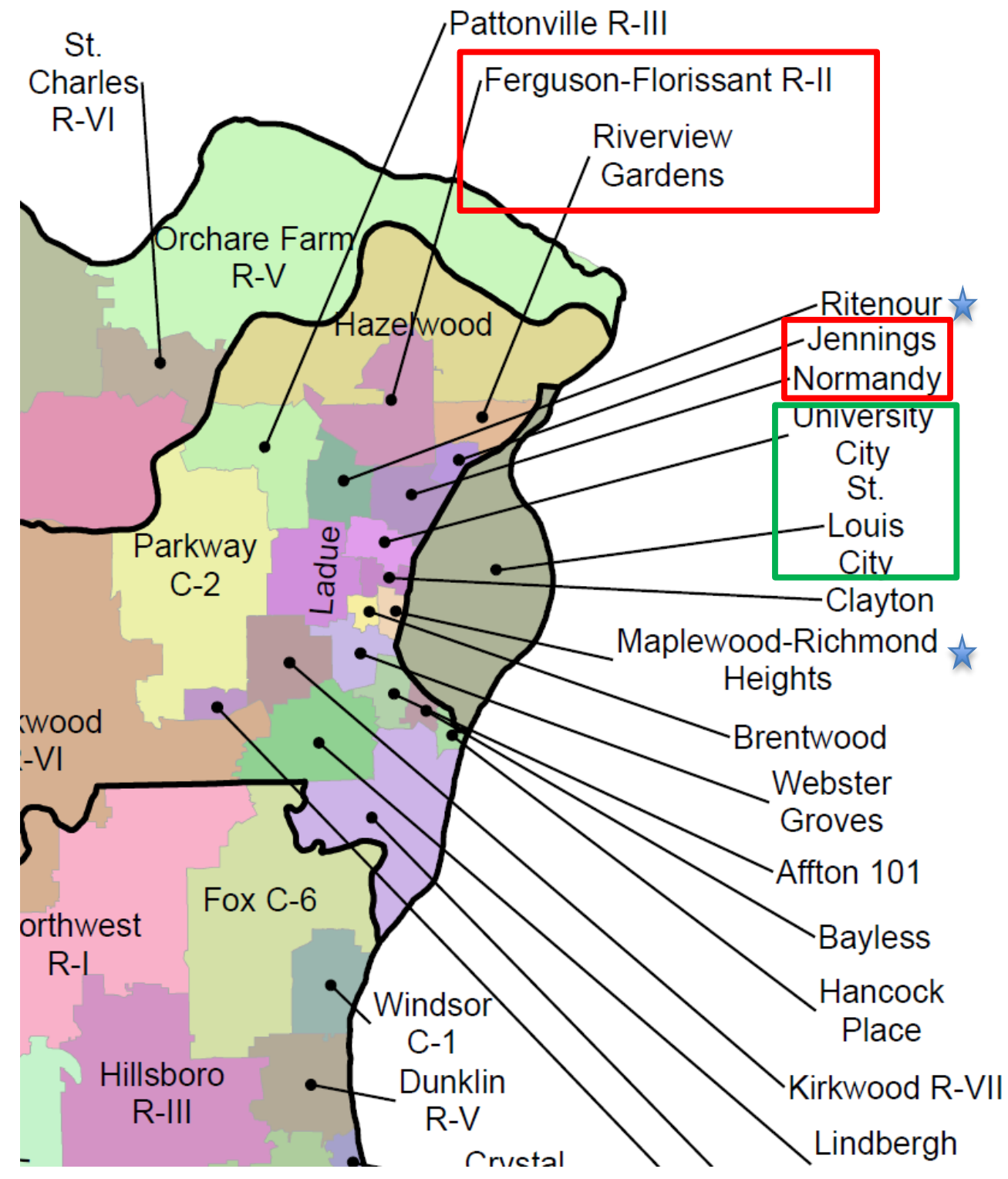

Notes: Baseline treatment districts are circled in red and include Ferguson, Jennings, Normandy, and Riverview Gardens. Extended treatment districts include Hazelwood, University City, and St. Louis City, which are circled in green. Stars indicate the districts that comprise Ferguson's synthetic control (Ritenour and Maplewood-Richmond Heights). The Eastern border is the Mississippi River, which separates Missouri from Illinois. Hazelwood's Northern border is the Missouri River. All bold black lines demarcate counties. Appendix Figure A.1 shows all counties in the St. Louis MSA. Source: Missouri Department of Elementary and Secondary Education. 
Figure 2. School Average "Percent Below Basic" in Math Rates

Figure 2.A. Percent Below Basic in Math, All Students

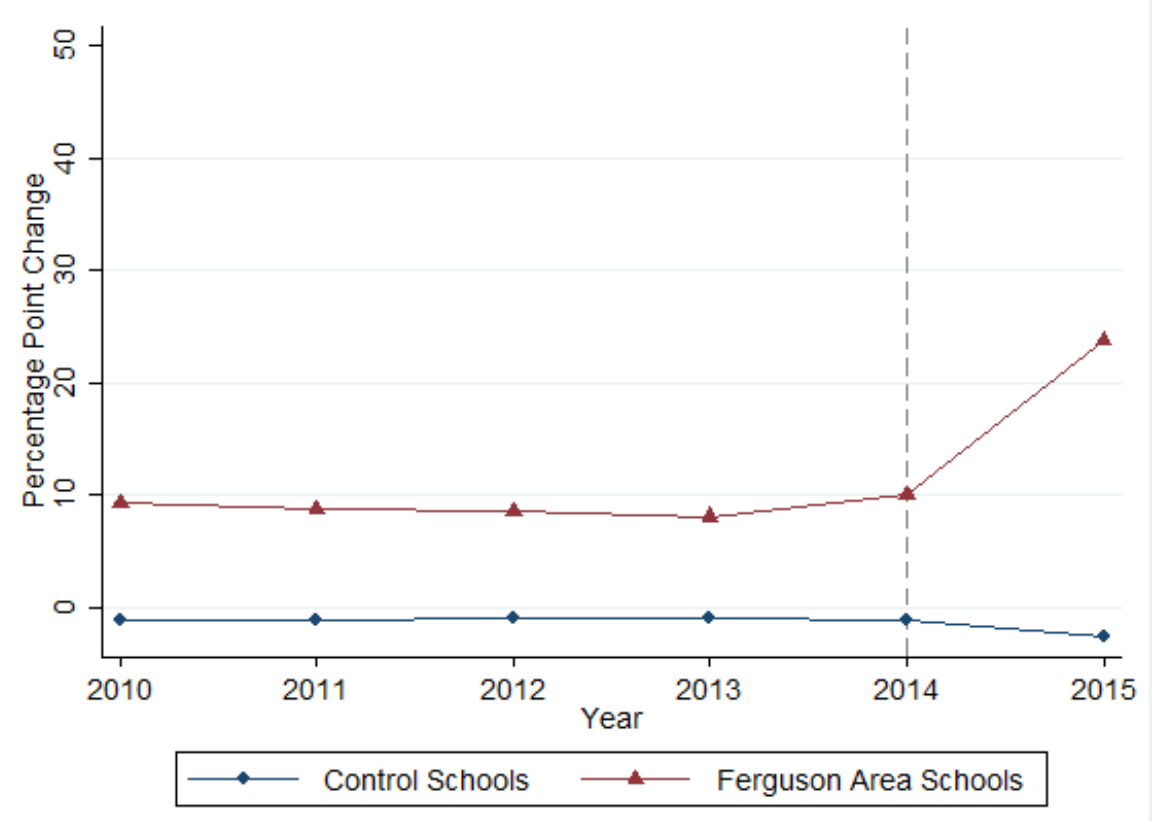

Figure 2.B. Percent Below Basic in Math, Super Subgroup

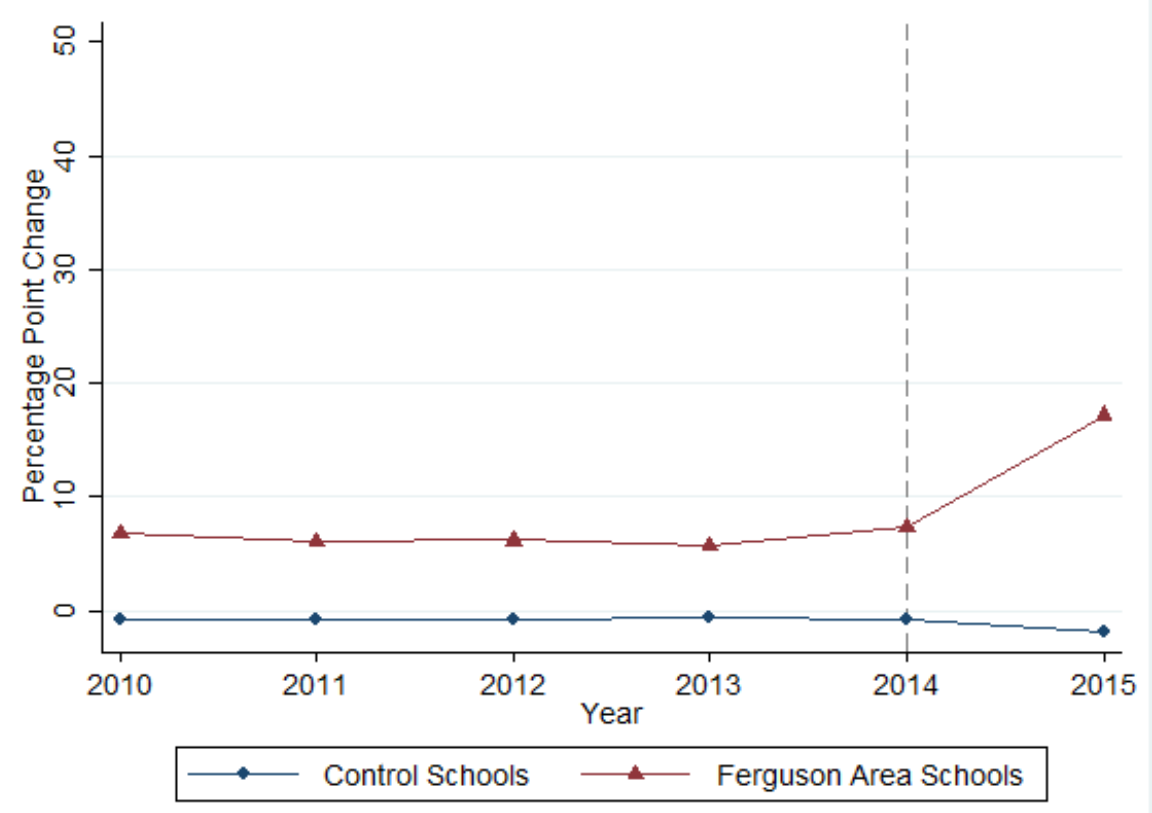

Notes: Ferguson Area Schools include all schools in four Missouri school districts including Ferguson, Jennings, Normandy, and Riverview Gardens. Control schools include all other public schools in the St. Louis MSA. Each dot represents the annual school average deviation from the statewide, year-specific mean. 
Figure 3. Distribution of Annual Within-School Changes in "Percent Below Basic" in Math

Figure 3.A: Changes from 2014 to 2015.

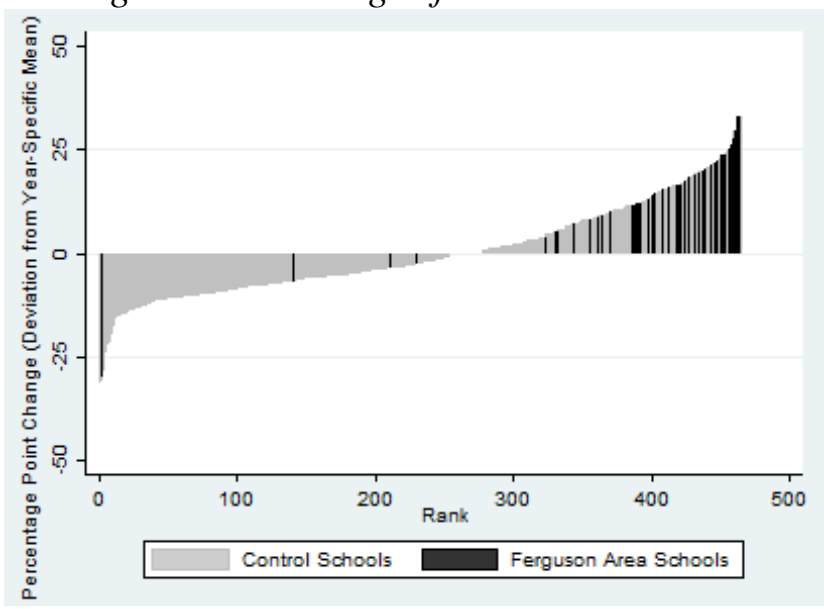

Figure 3.B: Changes from 2013-2014.

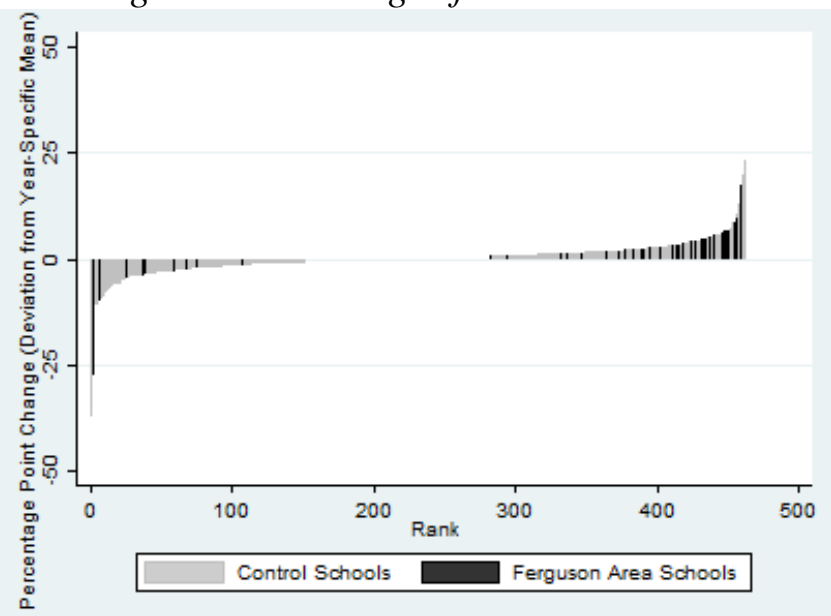

Figure 3.C: Changes from 2012-2013.

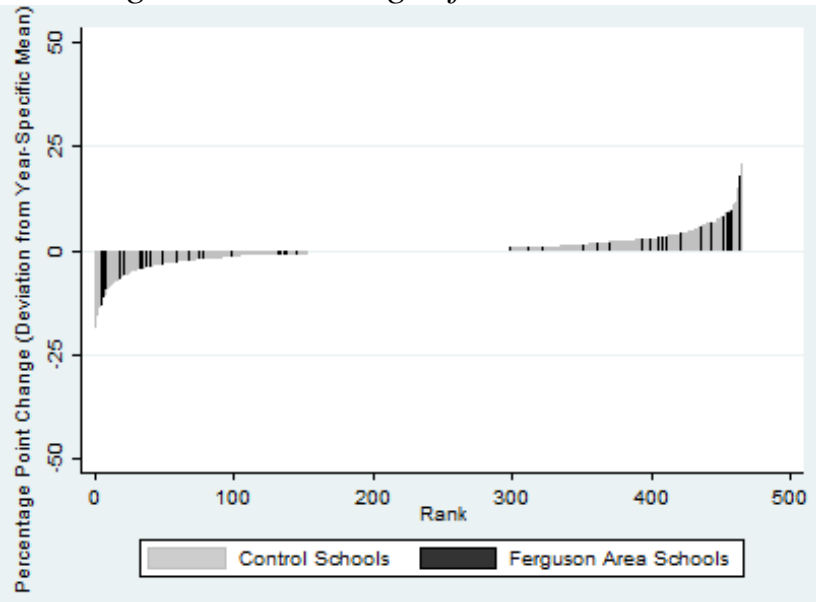

Notes: In panel A, Treatment $=54.5 \%$ of top $5 \%$ schools and $60.0 \%$ of top $1 \%$ schools. In panel $\mathrm{B}$, Treatment $=33.3 \%$ of top $5 \%$ schools and $20.0 \%$ of top $1 \%$ schools. In panel $\mathrm{C}$, Treatment $=$ $26.1 \%$ of top $5 \%$ schools and $20 \%$ of top $1 \%$ schools. 
Figure 4. Ferguson District and its Synthetic Control

Figure 4.A

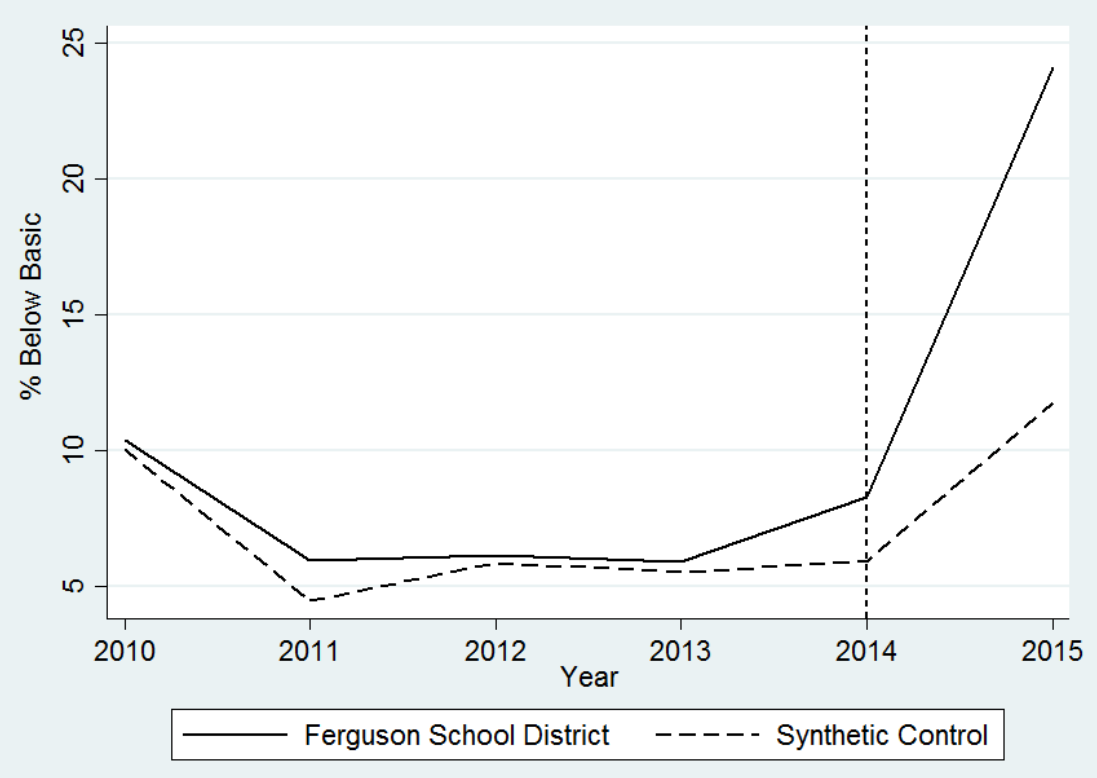

Figure 4.B

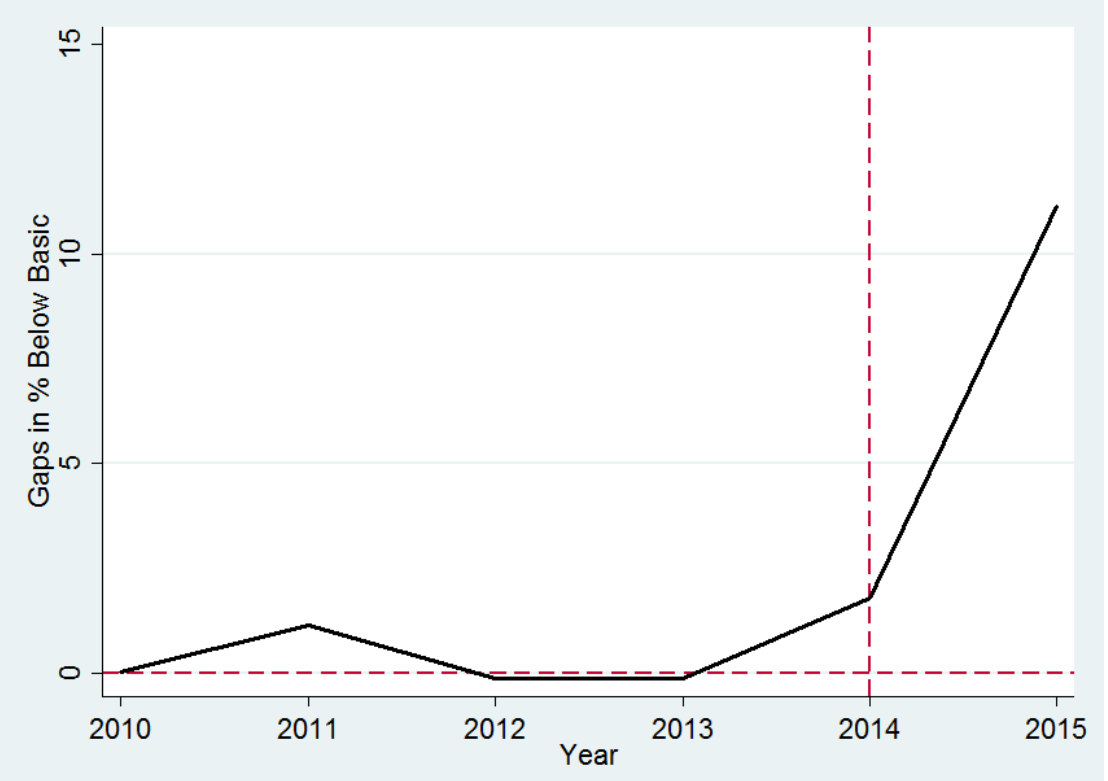

Notes: The synthetic control is the weighted average of Ritenour District (0.957) and Maplewood-Richmond Heights District (0.043). The Y axis in Figure 4.A measures the real and synthetic Ferguson's distance from the year-specific statewide average in district-level percent of students scoring below basic in math. The $\mathrm{Y}$ axis in Figure 4.B measures the difference in percent below basic between Ferguson and its synthetic control. 
Figure 5. Placebo Treatments in 2012 and 2013

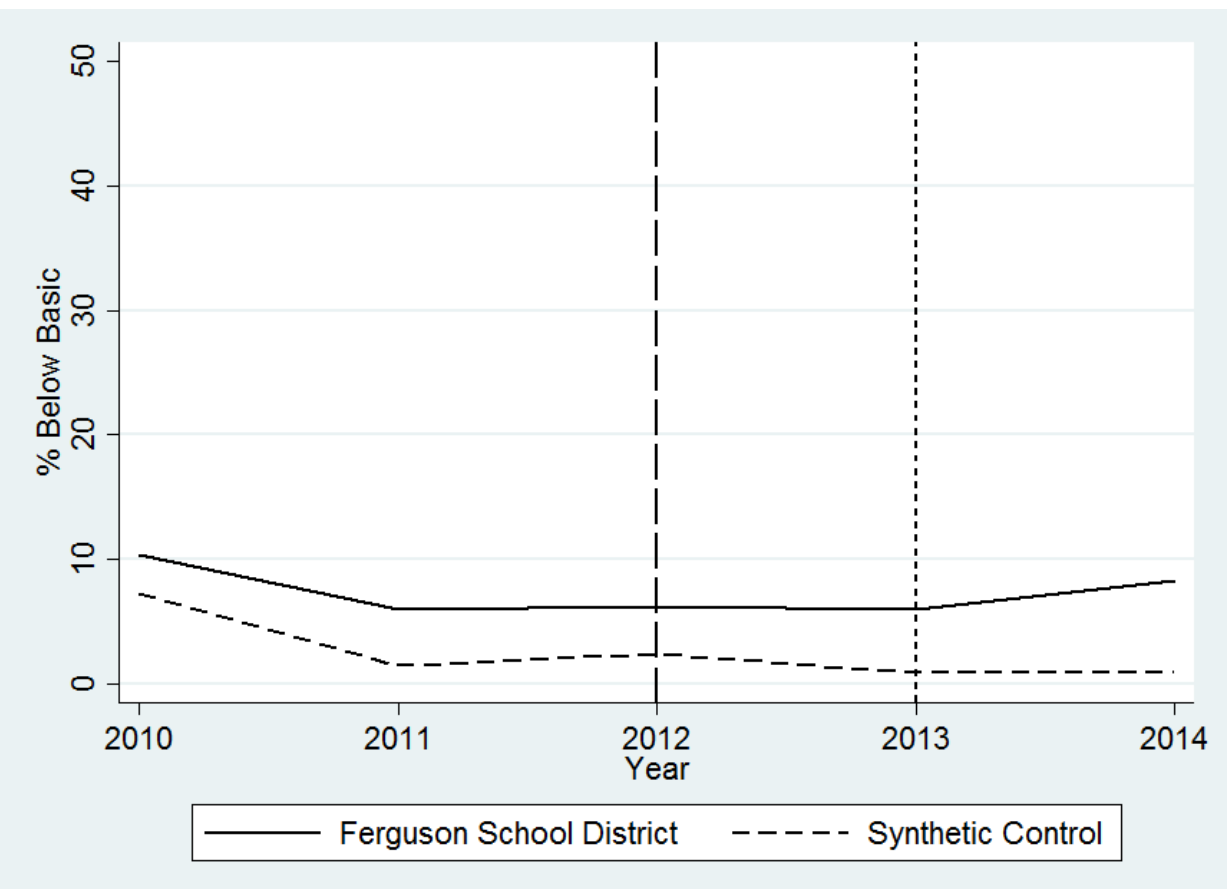

Notes: The synthetic control was re-estimated twice. In each case, data from the actual treatment year (2015) was excluded and the models instead assumed placebo treatments in 2012 and 2013, respectively. In the former, 2013 and 2014 are both post-treatment years. In the latter, only 2014 is post-treatment. Both cases offered Ritenour District as a synthetic Ferguson, which we plot alongside the actual Ferguson district for the actual pre-treatment years of 2010-2014. Since both placebos yield the same synthetic control, the two pictures are identical. 
Figure 6. Placebo Treatments in Untreated Districts

Figure 6.A

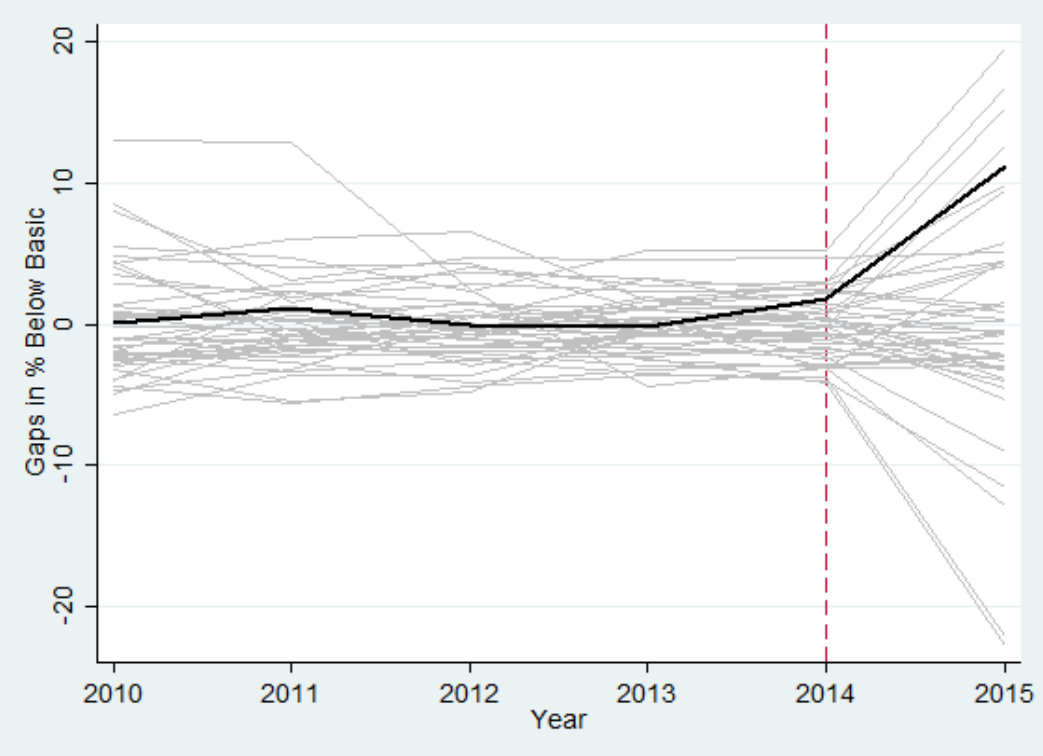

Figure 6.B

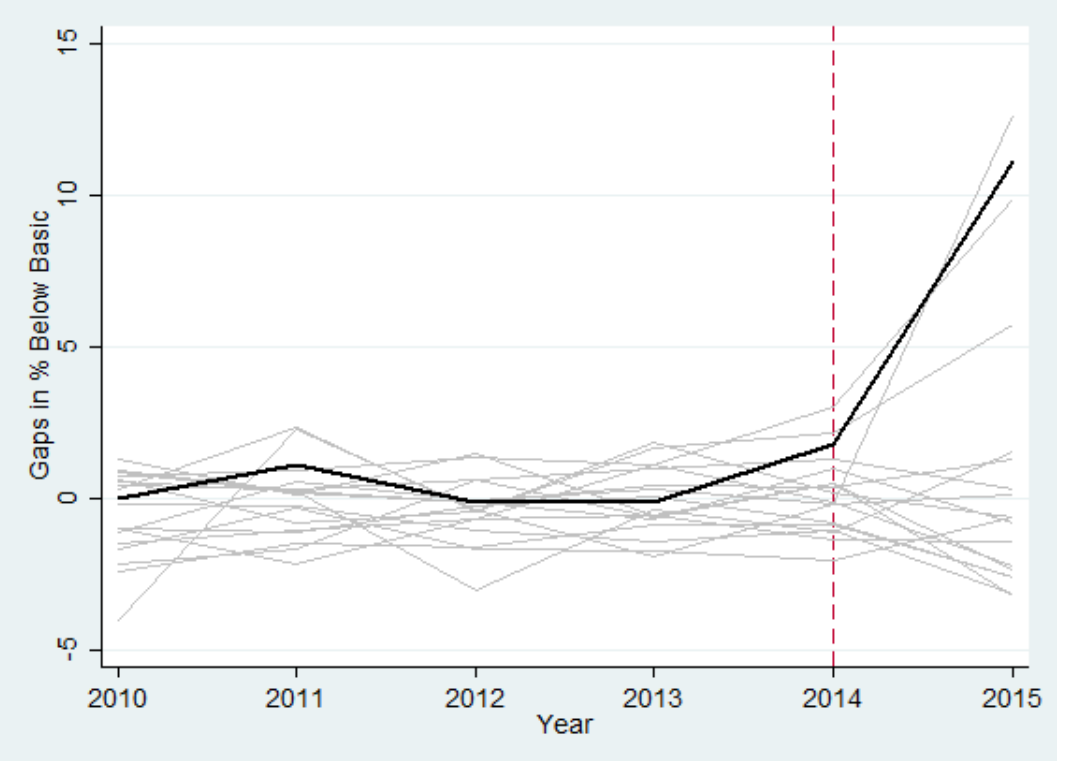

Notes: The bold black line represents the difference in percent below between Ferguson and its synthetic control. This is the same line plotted in Figure 4.B and, in 2015, represents the impact of the civic unrest on math achievement in Ferguson District. Synthetic controls were estimated for every other district in the MSA, except for other Ferguson-area districts considered as treated in the difference-in-differences analysis. Gray lines plot the difference between each placebo "treated district" and that district's synthetic control. Plots for all placebo districts are shown in Figure 6.A. Figure 6.B excludes the 26 placebo districts with pre-treatment Mean Square Predicted Error (MSPE) $\geq$ three times that of Ferguson's (Abadie et al., 2015). 
Table 1. Descriptive Statistics for Missouri Public Schools

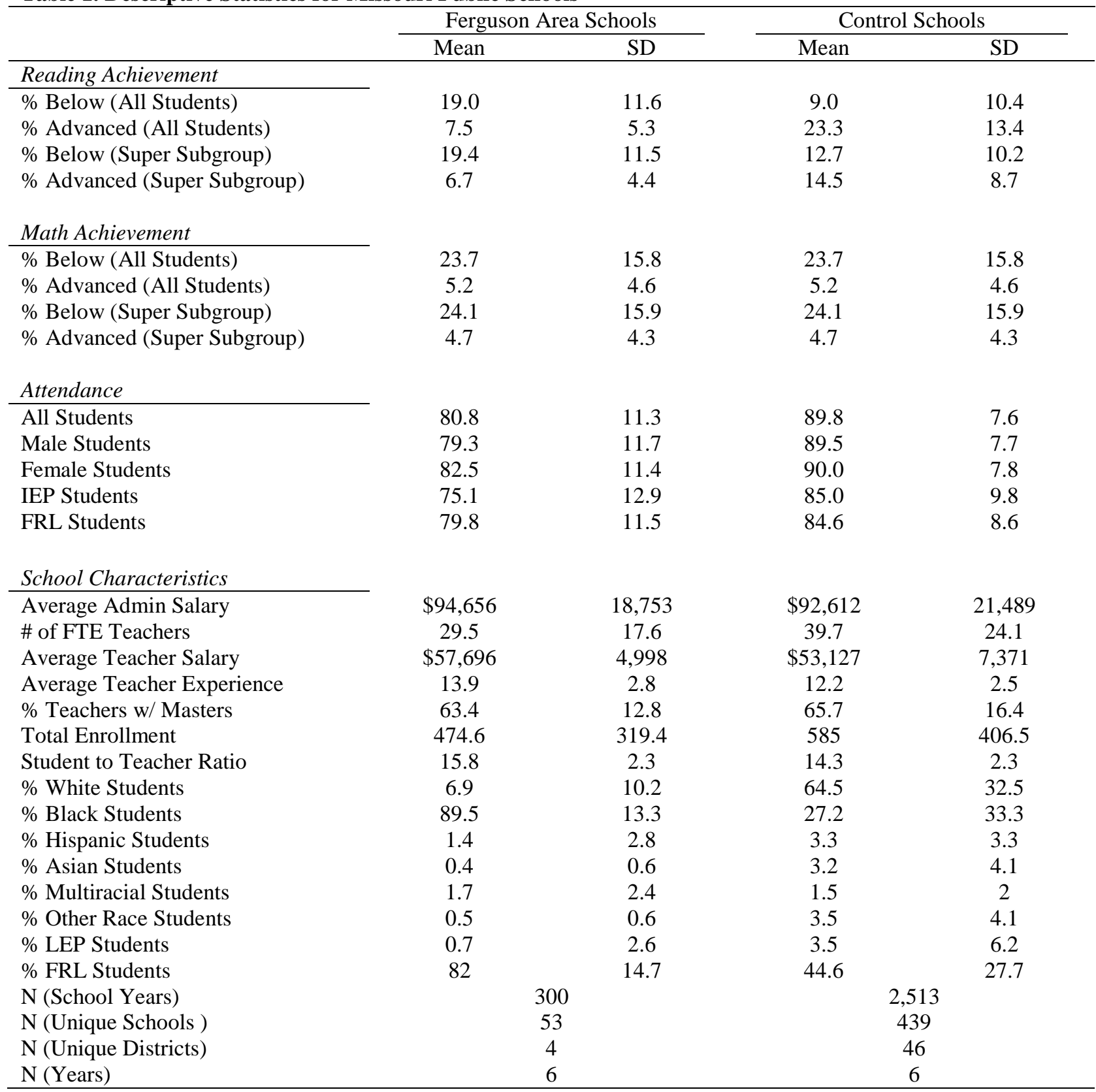

Notes: Control schools are schools in the St. Louis Metropolitan Statistical Area on the Missouri side of the Mississippi River. Ferguson-area (control) schools are schools in the following school districts: Ferguson, Normandy, Jennings, and Riverview Gardens. Super Subgroup includes high needs students who are black, Hispanic, low-income, or have an Individualized Education Plan (IEP). Attendance rates are the percentage of a school's students who were absent fewer than ten percent of school days (i.e., who were not chronically absent). 
Table 2. School Level Difference-in-Difference Estimates

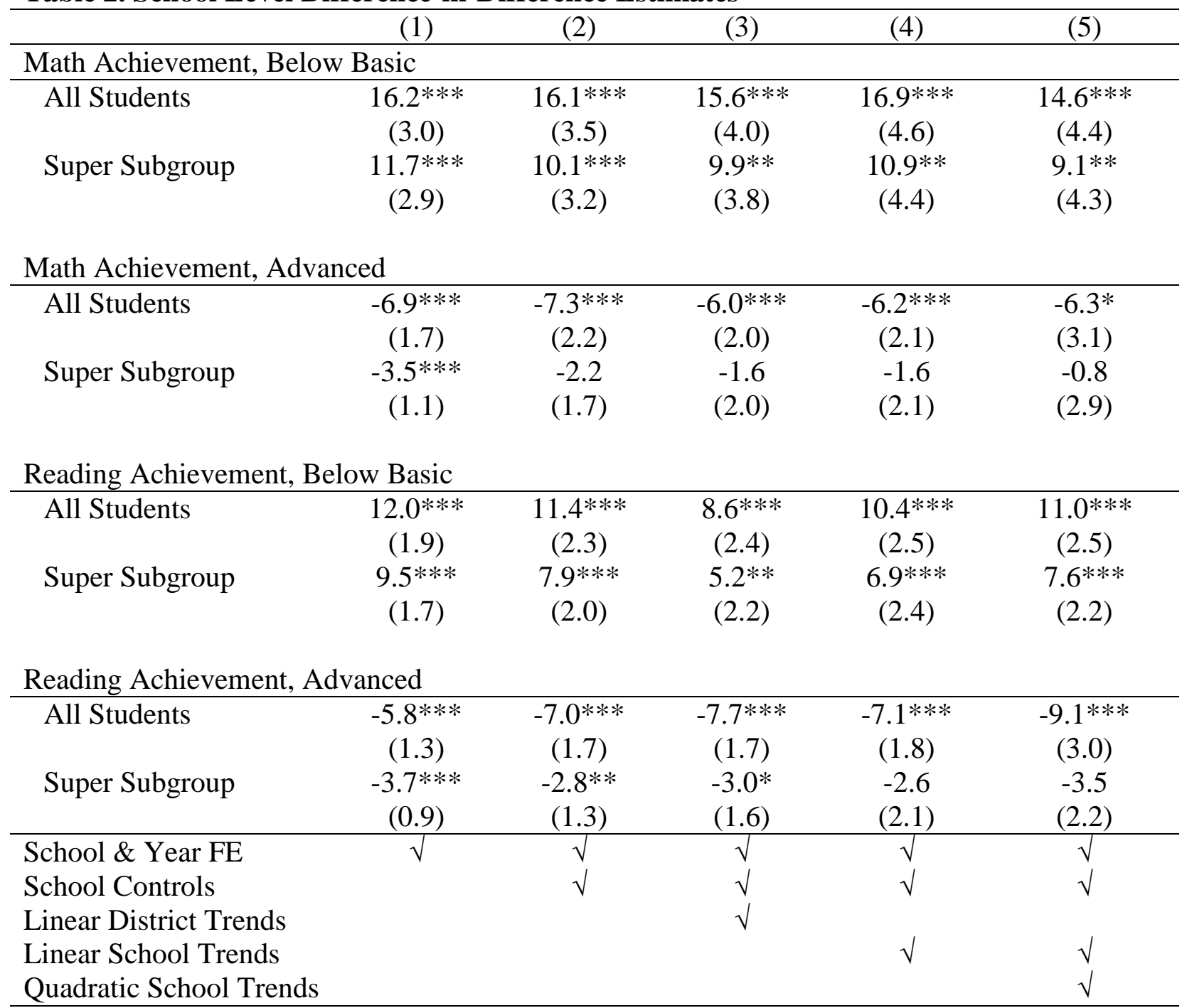

Notes: Each cell reports the estimate of $\tau$ for a unique regression. Outcomes are school performance rates for either all students or for super-subgroup (high needs) students who are black, Hispanic, eligible for free or reduced-price lunch (FRL), have an individual education plan (IEP), or English language learners (ELL). Each row represents a different dependent variable: percent below basic or percent advanced, in either math or reading. Standard errors are clustered by school district. The analytic sample contains 2,813 unique school-year observations, 50 unique districts, 492 unique schools, and six academic years (2010-2015). School controls include those summarized in table $1 . \mathrm{FE}=$ fixed effects. $* * * \mathrm{p}<0.01, * * \mathrm{p}<0.05$, and $* \mathrm{p}<0.1$. 
Table 3. School Level Math Achievement Event Study Estimates

\begin{tabular}{lccccc}
\hline & \multicolumn{2}{c}{ Below Basic } & & \multicolumn{2}{c}{ Advanced } \\
\cline { 2 - 3 } \cline { 5 - 6 } & All Students & Super Subgroup & & All Students & Super Subgroup \\
& $(1)$ & $(2)$ & & $(3)$ & $(4)$ \\
\hline $2011 \times$ Treated & -1.2 & $(1.2$ & -0.1 & 0.1 \\
& $(1.0)$ & $(1.1)$ & & $(0.7)$ & $(0.6)$ \\
$2012 \times$ Treated & $-2.3^{*}$ & -1.5 & 0.1 & 0.0 \\
& $(1.1)$ & $(1.2)$ & $(1.0)$ & $(0.9)$ \\
$2013 \times$ Treated & $-2.6^{* *}$ & $-2.1^{*}$ & 1.1 & 1.0 \\
& $(1.0)$ & $(1.2)$ & $(1.5)$ & $(1.4)$ \\
$2014 \times$ Treated & -1.4 & -0.9 & & 0.3 & 0.4 \\
& $(1.6)$ & $(1.6)$ & $(1.3)$ & $(1.1)$ \\
$2015 \times$ Treated & $14.5^{* * *}$ & $8.9^{* * *}$ & $-6.9^{* *}$ & -1.8 \\
& $(3.5)$ & $(3.0)$ & $(2.7)$ & $(2.0)$ \\
\hline School \& Year FE & $\sqrt{ }$ & $\sqrt{ }$ & $\sqrt{ }$ & $\sqrt{ }$ \\
School Controls & $\sqrt{ }$ & $\sqrt{ }$ & $\sqrt{ }$ & $\sqrt{ }$ \\
\hline
\end{tabular}

Notes: Each column reports the coefficient estimates on the interactions between the "treated school" and year indicators from a unique regression. Outcomes are school performance rates for both all students and for super-subgroup (high needs) students who are black, Hispanic, eligible for free or reduced-price lunch (FRL), have an individual education plan (IEP), or English language learners (ELL). Each row represents a different dependent variable: percent below basic or percent advanced, in either math or reading. Standard errors are clustered by school district. The analytic sample contains 2,813 unique school-year observations, 50 unique districts, 492 unique schools, and six academic years (2010-2015). School controls include those summarized in table $1 . \mathrm{FE}=$ fixed effects. $* * * \mathrm{p}<0.01, * * \mathrm{p}<0.05$, and $* \mathrm{p}<0.1$. 
Table 4. Geographic Heterogeneity in Effect of Unrest on Math Achievement

\begin{tabular}{lccccc}
\hline & \multicolumn{2}{c}{ Below Basic } & & \multicolumn{2}{c}{ Advanced } \\
\cline { 2 - 3 } \cline { 5 - 6 } & All Students & $\begin{array}{c}\text { Super } \\
\text { Subgroup }\end{array}$ & & All Students & $\begin{array}{c}\text { Super } \\
\text { Subgroup }\end{array}$ \\
& $(1)$ & $(2)$ & & $(3)$ & $(4)$ \\
\hline $2015 \times$ Ferguson & $20.7^{* * *}$ & $14.3^{* * * *}$ & & $-7.9^{* * *}$ & $(1.5$ \\
& $(3.2)$ & $(2.7)$ & & $(1.8)$ & $(1.7)$ \\
$2015 \times$ Jennings & $12.0^{* * *}$ & $7.8^{* * *}$ & & $-6.5^{* * *}$ & $-5.1^{* * *}$ \\
& $(2.1)$ & $(1.1)$ & & $(1.2)$ & $(0.6)$ \\
$2015 \times$ Normandy & $23.1^{* * *}$ & $17.9^{* * *}$ & & -3.2 & -1.3 \\
& $(3.1)$ & $(1.9)$ & & $(2.3)$ & $(1.4)$ \\
$2015 \times$ Riverview Gardens & $8.4^{* *}$ & 0.1 & & $-3.9^{*}$ & 2.5 \\
& $(3.6)$ & $(2.9)$ & & $(2.1)$ & $(2.1)$ \\
\hline School \& Year FE & $\sqrt{ }$ & $\sqrt{ }$ & & $\sqrt{ }$ & $\sqrt{ }$ \\
School Controls & $\sqrt{ }$ & $\sqrt{ }$ & & $\sqrt{ }$ & $\sqrt{ }$ \\
Linear School Trends & $\sqrt{ }$ & $\sqrt{ }$ & & $\sqrt{ }$ \\
\hline
\end{tabular}

Notes: $\mathrm{N}=2,813$. Each column reports the coefficient estimates on the interaction between the "treated school district" and 2015 indicators from a unique regression. Standard errors are clustered by school district. School controls include those summarized in Table 1. FE = fixed effects. Outcomes are school performance rates for both all students and for super-subgroup (high needs) students who are black, Hispanic, eligible for free or reduced-price lunch (FRL), have an individual education plan (IEP), or English language learners (ELL). $* * * \mathrm{p}<0.01, * * \mathrm{p}<0.05$, and $* \mathrm{p}<0.1$. 
Table 5. School-Level Difference-in-Difference Estimates by School Type

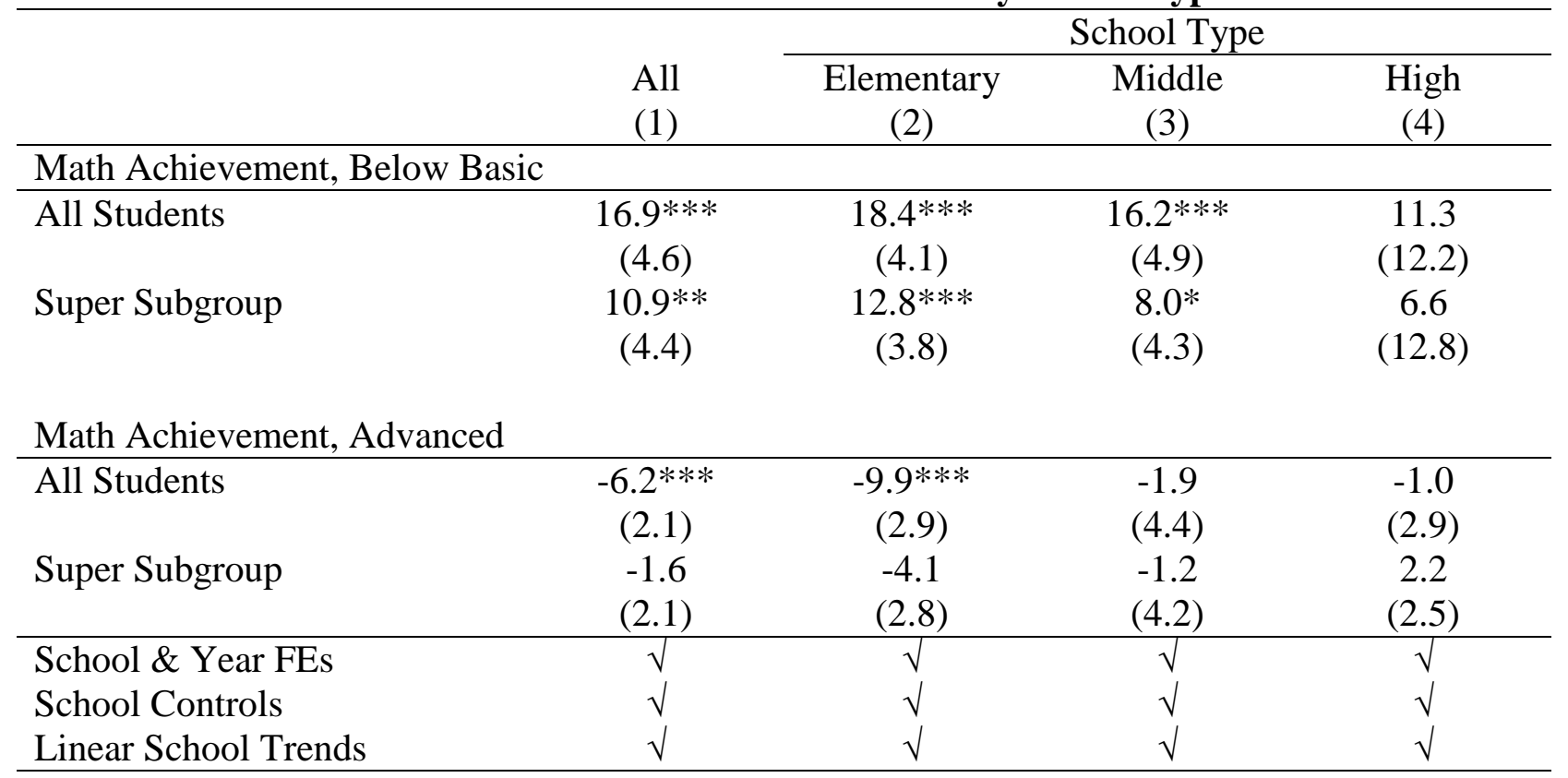

Notes: Each cell reports the estimate of $\tau$ for a unique regression. Outcomes are school performance rates for both all students and for super-subgroup (high needs) students who are black, Hispanic, eligible for free or reduced-price lunch (FRL), have an individual education plan (IEP), or English language learners (ELL). The coefficients in the "All" column are the same as the coefficients from column 4 in Table 2. Each row represents a different dependent variable: percent below basic and percent advanced. Standard errors are clustered by school district. The analytic sample contains 2,813 unique school-year observations, 50 unique districts, 492 unique schools, and six academic years (2010-2015). School controls include those summarized in table 1. $\mathrm{FE}=$ fixed effects. $* * * \mathrm{p}<0.01, * * \mathrm{p}<0.05$, and $* \mathrm{p}<0.1$. 
Table 6. Effects on Student Attendance

\begin{tabular}{|c|c|c|c|c|}
\hline \multirow[b]{2}{*}{ Outcome } & \multirow[b]{2}{*}{$\begin{array}{l}\text { All } \\
(1)\end{array}$} & \multicolumn{3}{|c|}{ School Type } \\
\hline & & $\begin{array}{c}\text { Elementary } \\
\text { (2) }\end{array}$ & $\begin{array}{l}\text { Middle } \\
\text { (3) }\end{array}$ & $\begin{array}{l}\text { High } \\
\text { (4) }\end{array}$ \\
\hline Total Attendance Rate & $\begin{array}{c}-3.1 * * * \\
(0.8)\end{array}$ & $\begin{array}{c}-4.2 * * * \\
(0.5)\end{array}$ & $\begin{array}{l}-1.8 \\
(2.3)\end{array}$ & $\begin{array}{l}-1.0 \\
(4.9)\end{array}$ \\
\hline Male Attendance Rate & $\begin{array}{c}-2.8^{* * * *} \\
(0.5)\end{array}$ & $\begin{array}{c}-3.9 * * * \\
(0.7)\end{array}$ & $\begin{array}{l}-2.9 \\
(2.0)\end{array}$ & $\begin{array}{c}0.6 \\
(4.9)\end{array}$ \\
\hline Female Attendance Rate & $\begin{array}{c}-3.5^{* * * *} \\
(1.0)\end{array}$ & $\begin{array}{c}-4.8^{* * * *} \\
(0.5)\end{array}$ & $\begin{array}{l}-0.4 \\
(2.6)\end{array}$ & $\begin{array}{l}-2.5 \\
(4.9)\end{array}$ \\
\hline IEP Attendance Rate & $\begin{array}{c}-2.8 * * * \\
(0.9)\end{array}$ & $\begin{array}{l}-3.8^{*} \\
(1.9)\end{array}$ & $\begin{array}{l}-4.5 \\
(3.5)\end{array}$ & $\begin{array}{l}-0.0 \\
(5.1)\end{array}$ \\
\hline FRL Attendance Rate & $\begin{array}{l}-0.8 \\
(0.6)\end{array}$ & $\begin{array}{c}-2.3 * * \\
(1.0)\end{array}$ & $\begin{array}{c}0.8 \\
(2.1)\end{array}$ & $\begin{array}{c}1.2 \\
(4.1)\end{array}$ \\
\hline $\begin{array}{l}\text { School \& Year FEs } \\
\text { School Controls } \\
\text { Linear District Trends }\end{array}$ & $\begin{array}{l}\sqrt{ } \\
\sqrt{ } \\
\sqrt{ }\end{array}$ & $\begin{array}{l}\sqrt{ } \\
\sqrt{ } \\
\sqrt{ }\end{array}$ & $\begin{array}{l}\sqrt{ } \\
\sqrt{ } \\
\sqrt{ }\end{array}$ & $\begin{array}{l}\sqrt{ } \\
\sqrt{ } \\
\sqrt{ }\end{array}$ \\
\hline
\end{tabular}

Notes: Each cell reports the coefficient estimate on the interaction between the "treated school" and 2015 indicators from a unique regression. Attendance rates reflect the percentage of a school's students who were absent fewer than 10 percent of school days. Standard errors are clustered by school district. School controls include those summarized in table 1. FE = fixed effects. IEP = Individualized Education Plan. FRL $=$ Free or reduced price lunch . $* * * \mathrm{p}<0.01, * * \mathrm{p}<0.05$, and $* \mathrm{p}<0.1$. 
Table 7. School-Level Triple-Difference Estimates

\begin{tabular}{|c|c|c|c|c|}
\hline & \multicolumn{2}{|c|}{ All Schools } & \multicolumn{2}{|c|}{ Elementary Schools } \\
\hline & (1) & (2) & (3) & (4) \\
\hline \multicolumn{5}{|l|}{ Below Basic, All Students } \\
\hline $2015 \times$ Black & $\begin{array}{c}13.0^{* * * *} \\
(2.4)\end{array}$ & $\begin{array}{c}10.5 * * * \\
(2.4)\end{array}$ & $\begin{array}{c}14.9 * * * \\
(2.3)\end{array}$ & $\begin{array}{c}12.2 * * * \\
(2.3)\end{array}$ \\
\hline 2015×Black×Ferguson Area & & $\begin{array}{c}7.7 \\
(4.7)\end{array}$ & & $\begin{array}{l}8.1 * * \\
(3.5)\end{array}$ \\
\hline $\mathrm{N}$ & \multicolumn{2}{|c|}{2,813} & \multicolumn{2}{|c|}{1,744} \\
\hline \multicolumn{5}{|l|}{ Below Basic, Super Subgroup } \\
\hline $2015 \times$ Black & $\begin{array}{c}6.8^{* * * *} \\
(2.2)\end{array}$ & $\begin{array}{l}4.6^{*} \\
(2.3)\end{array}$ & $\begin{array}{c}8.7 * * * \\
(2.2)\end{array}$ & $\begin{array}{c}6.1 * * * \\
(2.1)\end{array}$ \\
\hline 2015×Black $\times$ Ferguson Area & & $\begin{array}{c}6.9 \\
(5.1)\end{array}$ & & $\begin{array}{l}7.6^{*} \\
(3.9)\end{array}$ \\
\hline $\mathrm{N}$ & & & & \\
\hline \multicolumn{5}{|l|}{ Attendance Rate } \\
\hline $2015 \times$ Black & $\begin{array}{c}-2.5^{* * * *} \\
(0.4)\end{array}$ & $\begin{array}{c}-2.2^{* * *} \\
(0.5)\end{array}$ & $\begin{array}{c}-2.7 * * * \\
(0.5)\end{array}$ & $\begin{array}{c}-2.1 * * * \\
(0.6)\end{array}$ \\
\hline 2015×Black ×Ferguson Area & & $\begin{array}{l}-0.8 \\
(0.9)\end{array}$ & & $\begin{array}{c}-1.8^{* *} \\
(0.8)\end{array}$ \\
\hline $\mathrm{N}$ & \multicolumn{2}{|c|}{2,813} & \multicolumn{2}{|c|}{1,744} \\
\hline School \& Year FE & $\sqrt{ }$ & $\sqrt{ }$ & $\sqrt{ }$ & $\sqrt{ }$ \\
\hline School Controls & $\sqrt{ }$ & $\sqrt{ }$ & $\sqrt{ }$ & $\sqrt{ }$ \\
\hline Linear School Trends & $\sqrt{ }$ & $\sqrt{ }$ & $\sqrt{ }$ & $\sqrt{ }$ \\
\hline
\end{tabular}

Notes: Black is a binary indicator equal to one if the school's enrollment is more than 50\% black, and zero otherwise. All Ferguson-Area schools are more than 50\% black. Attendance rates reflect the percentage of a school's students who were absent fewer than 10 percent of school days. Standard errors are clustered by school district. School controls include those summarized in table $1 . \mathrm{FE}=$ fixed effects. $* * * \mathrm{p}<0.01, * * \mathrm{p}<0.05$, and $* \mathrm{p}<0.1$. 
Appendix Figure A.1. Map of St. Louis Metropolitan Statistical Area

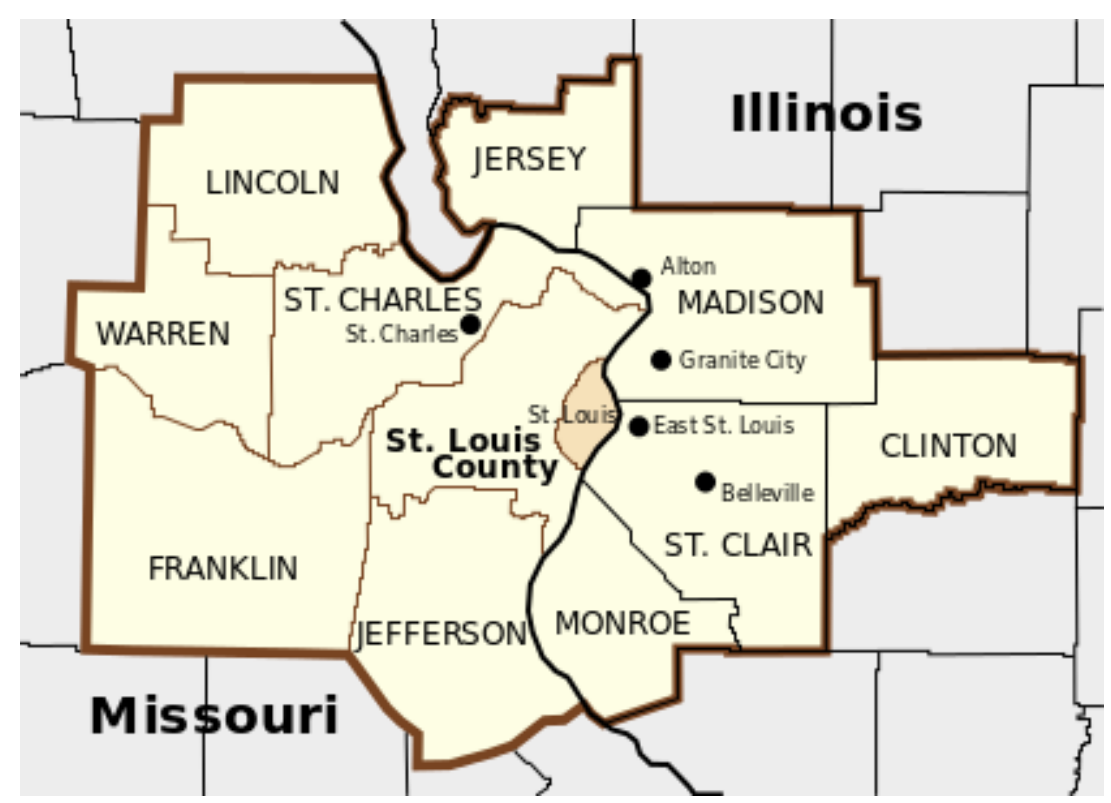

Source: Augusta 89 (File:St Louis MSA.png USGov) [CC BY-SA 3.0

(http://creativecommons.org/licenses/by-sa/3.0)], via Wikimedia Commons. 


\section{Appendix Figure A.2. School Average "Percent Below Basic" in Reading Rates}

Appendix Figure A.2.A: Reading, All Students

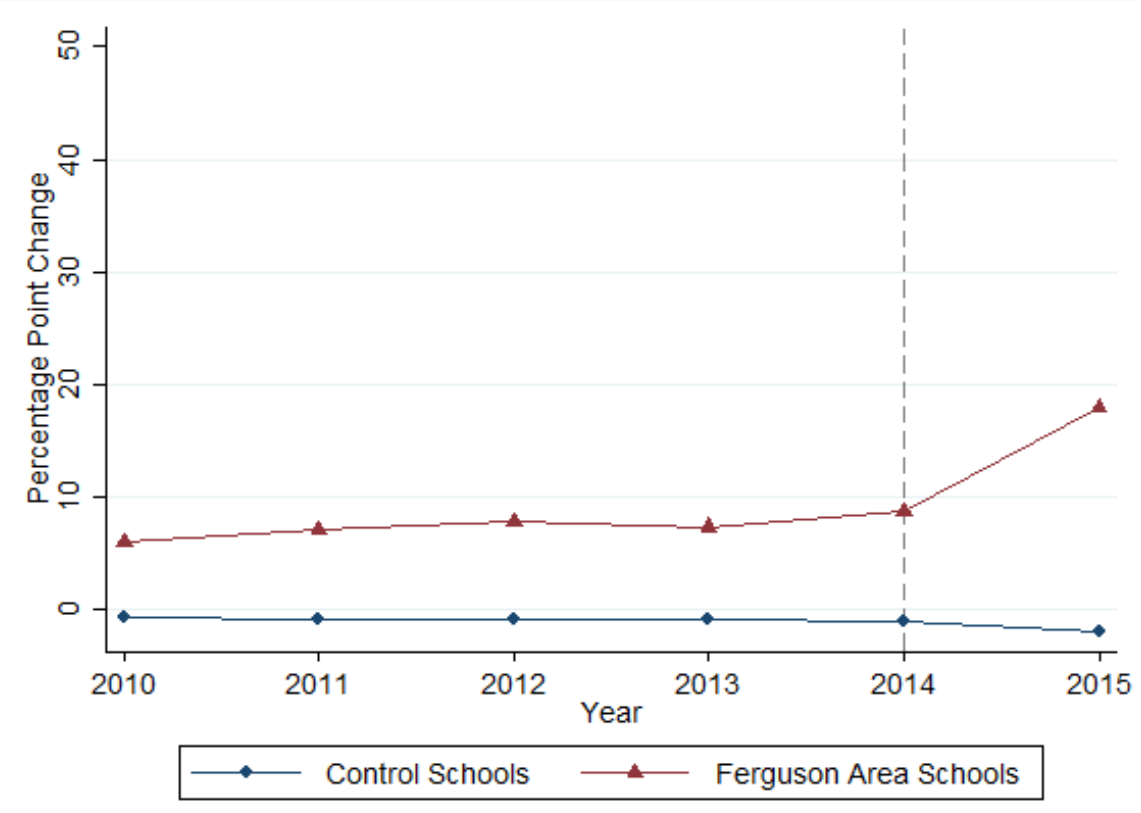

Appendix Figure A.2.B: Reading, Super Subgroup

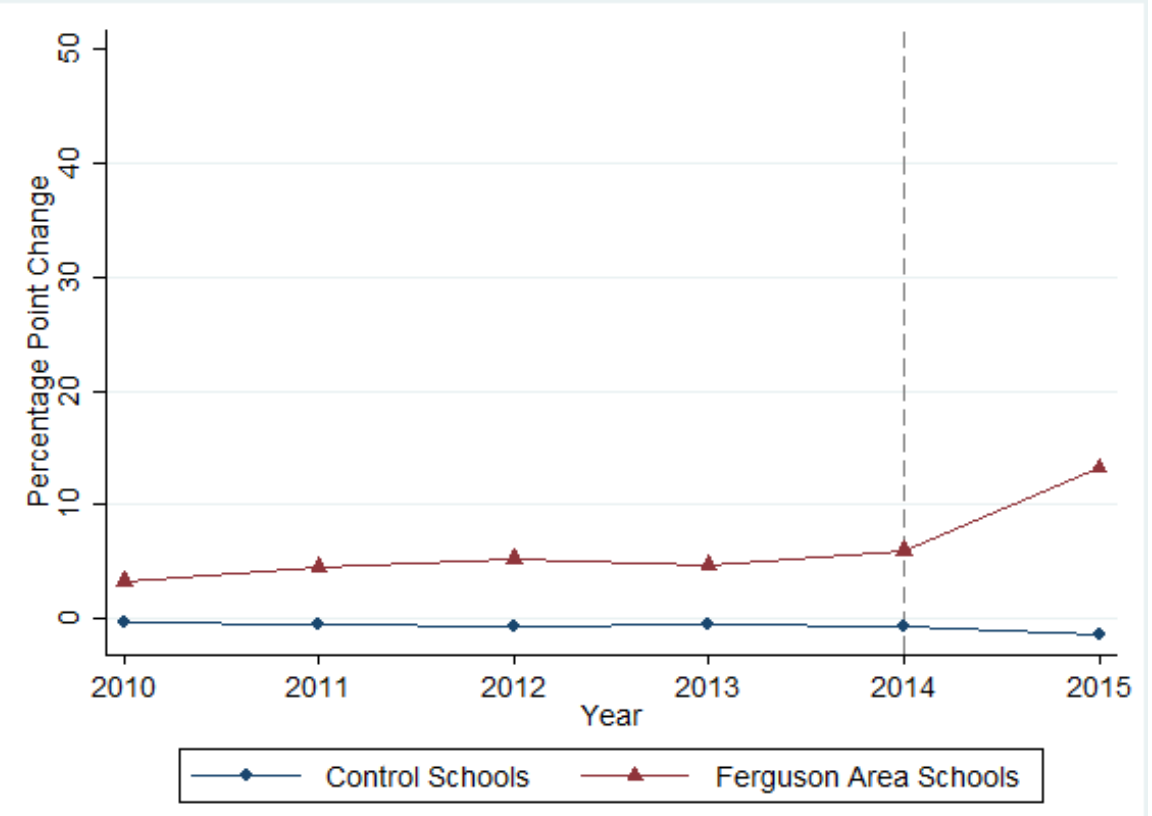

Notes: Ferguson Area Schools include all schools in four Missouri school districts including Ferguson, Jennings, Normandy, and Riverview Gardens. Control schools include all other public schools in the St. Louis MSA. Each dot represents the annual school average deviation from the year-specific mean. 
Appendix Table A.1. School Level Difference-in-Difference Estimates (Weighted)

\begin{tabular}{|c|c|c|c|c|c|}
\hline & (1) & (2) & (3) & (4) & (5) \\
\hline \multicolumn{6}{|c|}{ Math Achievement, Below Basic } \\
\hline \multirow[t]{2}{*}{ All Students } & $16.0 * * *$ & $16.2 * * *$ & $16.9 * * *$ & $18.0 * * *$ & $13.0^{* * *}$ \\
\hline & $(2.7)$ & (3.6) & $(5.1)$ & $(5.5)$ & $(4.0)$ \\
\hline \multirow[t]{2}{*}{ Super Subgroup } & $11.3^{* * *}$ & $9.8^{* *}$ & $10.9 * *$ & $11.7^{*}$ & 6.8 \\
\hline & $(2.5)$ & (3.7) & $(5.2)$ & (5.9) & (4.5) \\
\hline \multicolumn{6}{|c|}{ Math Achievement, Advanced } \\
\hline \multirow[t]{2}{*}{ All Students } & $-7.4 * * *$ & $-7.9 * * *$ & $-5.9 * * *$ & $-6.0 * * *$ & $-5.6^{*}$ \\
\hline & (1.6) & (2.2) & (1.9) & $(1.8)$ & (2.9) \\
\hline \multirow[t]{2}{*}{ Super Subgroup } & $-3.7 * * *$ & $-2.6^{*}$ & -2.0 & -1.8 & -1.1 \\
\hline & $(1.1)$ & (1.4) & (1.7) & (1.7) & (2.7) \\
\hline \multicolumn{6}{|c|}{ ELA Achievement, Below Basic } \\
\hline \multirow[t]{2}{*}{ All Students } & $10.7 * * *$ & $10.4 * * *$ & $7.3 * * *$ & $8.7 * * *$ & $9.8 * * *$ \\
\hline & $(1.6)$ & $(2.2)$ & $(2.0)$ & $(1.8)$ & (2.4) \\
\hline \multirow[t]{2}{*}{ Super Subgroup } & $8.6^{* * *}$ & $7.1 * * *$ & $4.2^{*}$ & $5.5^{* * *}$ & $6.6^{* *}$ \\
\hline & (1.5) & (2.1) & (2.1) & $(2.0)$ & (2.5) \\
\hline \multicolumn{6}{|c|}{ ELA Achievement, Advanced } \\
\hline \multirow[t]{2}{*}{ All Students } & $-4.4 * * *$ & $-5.4 * * *$ & $-5.4 * * *$ & $-4.6 * * *$ & $-5.0 * *$ \\
\hline & $(0.8)$ & (1.3) & $(1.2)$ & $(0.9)$ & $(2.0)$ \\
\hline \multirow{2}{*}{ Super Subgroup } & $-2.9 * * *$ & $-2.1^{* *}$ & -1.8 & -1.2 & -1.6 \\
\hline & $(0.6)$ & $(0.9)$ & (1.2) & (1.4) & (1.4) \\
\hline School \& Year FE & $\sqrt{ }$ & $\sqrt{ }$ & $\sqrt{ }$ & $\sqrt{ }$ & $\sqrt{ }$ \\
\hline School Controls & & $\sqrt{ }$ & $\sqrt{ }$ & $\sqrt{ }$ & $\sqrt{ }$ \\
\hline Linear District Trends & & & $\sqrt{ }$ & & \\
\hline Linear School Trends & & & & $\sqrt{ }$ & $\sqrt{ }$ \\
\hline Quadratic School Trends & & & & & $\sqrt{ }$ \\
\hline
\end{tabular}

Notes: Each cell reports the estimate of $\tau$ for a unique regression. All regressions are weighted by school size (enrollment). Outcomes are school performance rates for both all students and for super-subgroup students who are black, Hispanic, eligible for free or reduced-price lunch (FRL), have an individual education plan (IEP), or English language learners (ELL). Each row represents a different dependent variable: percent below basic or percent advanced, in either math or reading. Standard errors are clustered by school district. The analytic sample contains 2,813 unique school-year observations, 50 unique districts, 492 unique schools, and six academic years (2010-2015). School controls include those summarized in table $1 . \mathrm{FE}=$ fixed effects. $* * * \mathrm{p}<0.01, * * \mathrm{p}<0.05$, and $* \mathrm{p}<0.1$ 


\section{Appendix Table A.2. Difference-in-Difference Estimates (Broad Treatment Group)}

\begin{tabular}{|c|c|c|c|c|c|}
\hline & (1) & (2) & (3) & (4) & (5) \\
\hline \multicolumn{6}{|c|}{ Math Achievement, Below Basic } \\
\hline All Students & $\begin{array}{c}13.1 * * * \\
(2.2)\end{array}$ & $\begin{array}{c}12.6^{* * * *} \\
(1.8)\end{array}$ & $\begin{array}{c}12.6^{* * * *} \\
(1.8)\end{array}$ & $\begin{array}{c}12.6 * * * \\
(2.3)\end{array}$ & $\begin{array}{c}11.1 * * * \\
(1.9)\end{array}$ \\
\hline Super Subgroup & $\begin{array}{c}6.8^{* * * *} \\
(2.2)\end{array}$ & $\begin{array}{c}6.4 * * * \\
(1.6)\end{array}$ & $\begin{array}{c}6.4 * * * \\
(1.7)\end{array}$ & $\begin{array}{c}6.3 * * * \\
(2.2)\end{array}$ & $\begin{array}{c}5.6 * * * \\
(1.8)\end{array}$ \\
\hline \multicolumn{6}{|c|}{ Math Achievement, Advanced } \\
\hline All Students & $\begin{array}{c}-7.5 * * * \\
(1.6)\end{array}$ & $\begin{array}{c}-6.9^{* * * *} \\
(1.4)\end{array}$ & $\begin{array}{c}-5.6^{* * * *} \\
(1.2)\end{array}$ & $\begin{array}{c}-5.7 * * * \\
(1.6)\end{array}$ & $\begin{array}{c}-5.4 * * * \\
(1.5)\end{array}$ \\
\hline Super Subgroup & $\begin{array}{c}-2.9 * * * \\
(1.0)\end{array}$ & $\begin{array}{c}-2.8^{* * * *} \\
(0.9)\end{array}$ & $\begin{array}{c}-1.9 * * \\
(0.8)\end{array}$ & $\begin{array}{l}-2.1^{*} \\
(1.1)\end{array}$ & $\begin{array}{l}-1.3 \\
(1.2)\end{array}$ \\
\hline \multicolumn{6}{|c|}{ ELA Achievement, Below Basic } \\
\hline All Students & $\begin{array}{c}10.9 * * * \\
(1.7)\end{array}$ & $\begin{array}{c}10.4^{* * * *} \\
(1.4)\end{array}$ & $\begin{array}{c}8.7 * * * \\
(1.3)\end{array}$ & $\begin{array}{c}8.9 * * * \\
(1.6)\end{array}$ & $\begin{array}{c}9.4 * * * \\
(1.6)\end{array}$ \\
\hline Super Subgroup & $\begin{array}{c}7.4 * * * \\
(1.7)\end{array}$ & $\begin{array}{c}7.0 * * * \\
(1.4)\end{array}$ & $\begin{array}{c}5.2 * * * \\
(1.2)\end{array}$ & $\begin{array}{c}5.5^{* * * *} \\
(1.5)\end{array}$ & $\begin{array}{c}6.5^{* * * *} \\
(1.4)\end{array}$ \\
\hline \multicolumn{6}{|c|}{ ELA Achievement, Advanced } \\
\hline All Students & $\begin{array}{c}-5.8 * * * \\
(1.9)\end{array}$ & $\begin{array}{c}-5.3 * * * \\
(1.5)\end{array}$ & $\begin{array}{c}-5.3 * * * \\
(1.5)\end{array}$ & $\begin{array}{c}-5.3 * * \\
(2.0)\end{array}$ & $\begin{array}{l}-6.6^{* *} \\
(2.6)\end{array}$ \\
\hline Super Subgroup & $\begin{array}{l}-2.6 \\
(1.6)\end{array}$ & $\begin{array}{l}-2.2 \\
(1.3)\end{array}$ & $\begin{array}{l}-1.8 \\
(1.2)\end{array}$ & $\begin{array}{c}-1.9 \\
(1.7)\end{array}$ & $\begin{array}{l}-2.3 \\
(2.3)\end{array}$ \\
\hline School \& Year FE & $\sqrt{ }$ & $\sqrt{ }$ & $\sqrt{ }$ & $\sqrt{ }$ & $\sqrt{ }$ \\
\hline School Controls & & $\sqrt{ }$ & $\sqrt{ }$ & $\sqrt{ }$ & $\sqrt{ }$ \\
\hline Linear District Trends & & & $\sqrt{ }$ & & \\
\hline Linear School Trends & & & & $\sqrt{ }$ & $\sqrt{ }$ \\
\hline Quadratic School Trends & & & & & $\sqrt{ }$ \\
\hline
\end{tabular}

Notes: Each cell reports the estimate of $\tau$ for a unique regression, in which the treatment group was expanded to include three additional districts: Hazelwood, St. Louis City, and University City. Outcomes are school performance rates for both all students and for super-subgroup students who are black, Hispanic, eligible for free or reduced-price lunch (FRL), have an individual education plan (IEP), or English language learners (ELL). Each row represents a different dependent variable: percent below basic or percent advanced, in either math or reading. Standard errors are clustered by school district. The analytic sample contains 2,813 unique school-year observations, 50 unique districts, 492 unique schools, and six academic years (2010-2015). School controls include those summarized in table $1 . \mathrm{FE}=$ fixed effects. $* * * \mathrm{p}<0.01, * * \mathrm{p}<0.05$, and $* \mathrm{p}<0.1$. 
Appendix Table A.3. School-Level Difference-in-Difference Estimates by Grade

\begin{tabular}{lcccc}
\hline & Grade 3 & Grade 5 & Grade 8 & Algebra 1 \\
& $(1)$ & $(2)$ & $(3)$ & $(4)$ \\
\hline All Students & \multicolumn{5}{c}{} & & \\
\hline Below Basic & $16.6^{* * *}$ & $18.7^{* * *}$ & 7.0 & 6.0 \\
& $(5.8)$ & $(4.4)$ & $(5.2)$ & $(11.4)$ \\
Advanced & $-9.5^{*}$ & $-5.7^{* * *}$ & -1.7 & -1.2 \\
& $(4.8)$ & $(1.9)$ & $(3.3)$ & $(4.3)$ \\
$\mathrm{N}$ & 1,716 & 1,668 & 601 & 879 \\
& & & & \\
\hline School \& Year FE & $\sqrt{ }$ & $\sqrt{ }$ & $\sqrt{ }$ & $\sqrt{ }$ \\
School Controls & $\sqrt{ }$ & $\sqrt{ }$ & $\sqrt{ }$ & $\sqrt{ }$ \\
Linear School Trends & $\sqrt{ }$ & $\sqrt{ }$ &
\end{tabular}

Notes: Each cell reports the estimate of $\tau$ for a unique regression. Outcomes are school performance rates for all students. Each row represents a different dependent variable: percent below basic and percent advanced. Standard errors are clustered by school district. The analytic sample contains 2,813 unique school-year observations, 50 unique districts, 492 unique schools, and six academic years (2010-2015). School controls include those summarized in table 1 . FE = fixed effects. $* * * \mathrm{p}<0.01, * * \mathrm{p}<0.05$, and $* \mathrm{p}<0.1$. 